\title{
The importance of the Great War compared to long-term developments in restructuring the rural landscape in Flanders (Belgium)
}

\author{
Dries Claeys ${ }^{1}$, Celina Van Dyck ${ }^{2}$, Gert Verstraeten $^{2}$, Yves Segers ${ }^{1}$ \\ Published in Applied Geography, 111 (2019), https://doi.org/10.1016/j.apgeog.2019.102063
}

\footnotetext{
${ }^{1}$ KU Leuven, Interfaculty Centre for Agrarian History, Naamsestraat 63, B-3000 Leuven, Belgium
}

${ }^{2}$ KU Leuven, Division Geography and Tourism, Department Earth and Environmental Sciences, Celestijnenlaan 200E, B-3001 Heverlee, Belgium

Corresponding author: Dries Claeys, dries.claeys@kuleuven.be

\begin{abstract}
The centenary of the Great War has amplified the voices that advocate the preservation of remaining war traces in the Belgian landscape. Modern technologies, such as Lidar, have recently highlighted that much war heritage is still preserved either at or below the surface, including mine craters, shell holes and trenches. However, these traces are largely hidden from the human eye. Less is known about the impact of the Great War on the overall landscape properties and the changing experience of the rural landscape. In this study, changes in land use and landscape structure since the mid- $19^{\text {th }}$ century were reconstructed for four study sites in Flanders that experienced the Great War differently. Historical maps and aerial photography were combined to produce time series of landscape properties, time depth maps and landscape fragmentation and diversity metrics. The interpretation of changes in land use and landscape patterns reveals that the Great War and post-war land recovery did only mark a break for some landscape elements. For two study sites along the Belgian front that were intensively degraded by the war activities, no significant difference in landscape evolution could be identified compared to two study sites that hardly suffered during the Great War. For the most part, long-term socio-economic developments eroded the significance of the war as a short-term cataclysmic event.
\end{abstract}

Keywords: aerial photography, agricultural history, First World War, historical geography, landscape change 


\section{Introduction}

Between 1914 and 1918, the western part of Flanders was the theatre of fierce battles. Four years of positional warfare did not only destroy the medieval town of Ypres, but also devastated the surrounding countryside. The use of modern weaponry, combined with the immobility of trench warfare, ruined almost 80,000 houses and thousands of acres of farmland (Stichelbaut et al., 2013; Claeys, 2017). Within the framework of the Great War centenary, many voices in Belgium have advocated the need to preserve the war heritage that is still present, in particular across the region of Ypres (Figure 1). Recently, the Flemish government has made efforts to turn the former front line into a UNESCO world heritage site (100 Jaar Groote Oorlog, 2011: 41; Flanders Heritage Agency, 2017). In the context of the centenary of the mine battle of Messines in June 2017, it was announced that nine remaining mine craters would be preserved as part of a commemorative landscape (Bourgeois, 2017). The centenary has increased the awareness of the Great War not only amongst policy makers and heritage institutions, but also amongst scientists. Over the last decade, intense geoarchaeological research, often making use of modern technologies like Lidar and geophysical prospection, have revealed that the former Belgian front, and even some inland sites, is still dotted with traces of war activities (e.g. Dewilde et al., 2007; Saey et al., 2013; Gheyle et al., 2016; Gheyle et al., 2018). A vast number of buried trenches, partly infilled mine craters, nearly levelled shell holes, remains of shelters, etc. are still preserved in the landscape. Whilst several of these remains are visible to the eye at some locations that were not restored after war, mainly in forested areas, the majority of these remains are not visible landscape features anymore but can only be found by use of these modern technologies. If these discoveries of the extensive 'hidden' war landscape could only be found recently (e.g. Gheyle et al., 2018), the question raises to what extent the Great War, and its infamous destruction of the landscape along the frontline in particular, have impacted the landscape in a more holistic way.

Since Fernand Braudel's influential La Méditerranée (1949), most studies of historical landscape change have focused on long-term developments. Historical events were often disregarded in favor of more structural, social and economic influences of landscape development (e.g. Lambin and Geist, 2006; Bicik et al. 2015; Antrop, 2005). However, there has been a growing attention for the courte durée and the impact of natural and anthropogenic hazards as driving forces for landscape transformations (see for example Bürgi et al., 2004; 
Hostert et al., 2011; Khan et al., 2015). In Belgium and France, several authors have indicated that the Great War indeed had a profound impact on rural and urban landscapes (Clout, 1996; Stichelbaut, 2017a). However, only few studies have taken into account its longitudinal effects (Chielens et al., 2006; Hupy and Schaetzl, 2006). Has the landscape changed because of the Great War in such a way that humans perceive it differently before and after the war? Has there been a major change in landscape properties including land use, structure and visibility following the Great War? Did the war destruction of the rural landscape and the consequent reconstruction process result in radically different land use and landscape structures? Or did these events largely go unnoticed in a more long-term perspective whereby landscape dynamics are steered mainly by hidden socio-economic processes? These questions fit in with recent studies that indicate how natural and anthropogenic hazards can permanently reshape affected areas and give counterweight to historical research that stresses the importance of structural, socio-economic driving forces (Geertsema et al., 2009; Westing, 2013; Antrop, 2005).

This paper aims to analyze the extent to which the Great War interfered with long-term evolutions of land use and landscape structures. The impact of the Great War is evaluated within a larger chronological framework that runs from the mid- $19^{\text {th }}$ century to the beginning of the $21^{\text {th }}$ century. Four case study villages are investigated which represent different agricultural regions and different degrees of wartime devastation. For the evaluation of landscape dynamics, historical topographic maps and military aerial photographs are combined with a heterogeneous selection of sources. These landscape dynamics are discussed within the broader historiography on the physical impact of middle- and long-term (economic and demographic) driving forces.

\section{Study Areas}

In this study, we analyzed the changes in landscape structure and land use for four municipalities in Flanders, each of which experienced a different degree of disturbance during the Great War: Merkem, Wijtschate, Liezele and Borlo-Buvingen (Figure 2). The study areas were defined by municipal boundaries (from 1914), which allowed the integration of population census data. Borlo and Buvingen are two small adjacent municipalities (resp. 3.8 and $3.4 \mathrm{~km}^{2}$ ) situated in the fertile loam region of central Belgium. Both villages combined had 933 inhabitants at the start of the Great War (Vrielinck, 2000: 1678-9, 1682-3). Borlo and Buvingen were occupied shortly after German troops invaded Belgium in August 1914 and 
witnessed no severe devastation throughout the four wartime years. Although German occupation weighed on the farmers in the region, agriculture in Borlo-Buvingen restored quickly after 1918. Liezele (6.5 km²; 1158 inhabitants in 1910; Vrielinck, 2000: 1722-3), on the contrary, suffered heavily during the Siege of Antwerp (September-October 1914). As part of the National Redoubt, and in order to protect the city and port of Antwerp, the Belgian Engineering Corps burned down the village in order to better observe the advancing German troops. Yet after more than a week of intensive battles, the German artillery appeared to be too strong. Hence, the Belgian Army was forced to retreat to the North Sea coast (Gils and Schokkaert, 1990; De Vos et al., 2014; Gheyle et al., 2014).

Here, in the westernmost part of the country, the front line would stabilize between the towns of Nieuport and Ypres. Between 1914 and 1918, the plains of West Flanders would remain one of the most deadly theatres of the Great War. One of the municipalities situated on the front line was Merkem $\left(26.8 \mathrm{~km}^{2}\right)$. Most of its 3700 inhabitants lived in the village center, on the border of the Polders (= medieval reclaimed coastal tidal flats) and the sandy and silt loam hilly regions of Belgium (Vrielinck, 2000: 1730-1). The topography is typically flat, with maximal heights of ten meters above mean sea level. It is this geographical position that defined the strategic role of Merkem and its neighboring villages during the war. Situated on the banks of the Yser River, large stretches of Merkem's territory were deliberately flooded by the Belgian Army from November 1914 onwards. The inundation of the Yser River was the cornerstone of the Belgian Army's attempt to prevent the German troops from reaching the ports of Northern France. As their plan succeeded, the inundations marked the start of a positional warfare that would last until the fall of 1918. By that time, Merkem was already partially destroyed as the result of continuous shelling and gunfire. However, the village would suffer complete annihilation during the Third Battle of Ypres in 1917. This was also the case for Wijtschate $\left(26.3 \mathrm{~km}^{2}\right)$, the fourth village under study, situated only $7 \mathrm{~km}$ south of Ypres in the fertile loamy soils in the south of West Flanders. Just like in the three previous cases, Wijtschate had a distinct rural character and thus rather small population figures. In 1910, Wijtschate had 3521 inhabitants (Vrielinck, 2000: 1778-9). In contrast with other parts of this province, the topography here is much more pronounced. Wijtschate itself was located on an 85-meter high ridge, towering 50-60 $\mathrm{m}$ above the surrounding valleys, and thus had a significant strategic position during the war. This explains why the village was so fiercely fought over by British and German forces. The Battle of Messines (June 1917) in particular turned the village into a moonscape, through the explosion of nineteen mine galleries. The intensity of destruction 
resulted in the fact that the traces of the Great War are visible in the regional landscape to this very day (Gheyle et al., 2018).

\section{Material \& Methods}

Changes in land use and landscape structure were analyzed for the four study areas, and this for the period 1861-2001, using historical topographic maps and aerial photographs. Land use and structural landscape features were digitized following a common legend for all time slices and consequently analyzed with ArcMap10.3. The various data collection and processing steps are detailed below.

\subsection{Data collection}

Historical maps and aerial photographs were collected for eight time periods between 1861 and 2001 (Figure 3). The first time period (1861-1871) makes use of the first official topographic maps $(1 / 20,000)$ made by the Belgian Dépôt de la Guerre in the mid-19 ${ }^{\text {th }}$ century. The second timeframe contains maps dating from the beginning of the $20^{\text {th }}$ century (1904-1914) and are a revision of the first topographic map series. Time periods three and four are reconstructed using aerial photographs taken during the Great War by Allied forces, and represent the beginning and end of the war period respectively (Figure 4). These pictures are (near) vertical black-andwhite photographs, and were mostly taken at an altitude of 1500 to 2500m (Stichelbaut, 2009: 115). Given the static nature of trench warfare, the vast majority of photographs only depict the front zone or its immediate hinterland. For this reason, aerial photographs of Liezele and Borlo-Buvingen are not available. The eventual selection contains 301 aerial photographs that cover the areas of Merkem and Wijtschate. The quality, date as well as the areal coverage of the images were taken into account during the selection process. Every WWI photo had enough detail to identify every single tree of hedge. The fifth timeframe (1940-1944) consists of aerial photographs from the Aerial Reconnaissance Archives held by the Royal Commission on the Ancient and Historical Monuments of Scotland (RCAHMS), Edinburgh. These archives contain 5.5 million WWII photos of Western Europe, including aerial photographs of Merkem, Wijtschate, Liezele and Borlo-Buvingen. In total 78 photographs were selected based on quality, date and area coverage to create a full coverage map. The selection consisted of vertical black-and white photos, produced in a three year time span (1942-1945) and at a scale between $1 / 3000$ and 1/67,000 (two photos had a scale of 1/250,000). The last three time periods are all 
based on post-war topographic maps made by the National Geographic Institute (NGI) of Belgium (Table 1). These topographic maps are produced at a 1/25,000 (c. 1960) or 1/10,000 (c. 1970, 2000) scale.

\subsection{Data processing}

As a complex and holistic concept, landscapes can be analyzed in many different ways following many different techniques (Antrop, 2000). Since historic maps and aerial photographs must be gathered to investigate long-term land use change, automated remote sensing techniques and pixel-based classifications are not applicable. For this reason, the digitalization and classification must be performed manually.

The collected data were processed using ArcMap 10.3. First, the analogue images and maps were scanned and georeferenced in the Belgium Lambert 1972 coordinate system. For the georeferencing of aerial photographs, a minimum of ten ground control points are chosen and dispersed over the images. The maps of the seventh timeframe (1978-1993) are thereby used as reference maps. Because field parcel boundaries are often the only recognizable elements in the ruined war landscape, cadastral maps are used as well to georeference the aerial photographs from the end of the Great War following the procedure described by Stichelbaut (2009). A second order polynomial transformation was used during the georeferencing processing step. The images were resampled using bilinear interpolation. The mean RMSE ran up to 2.2 meters for the WWI images and 1.7 meters for the WWII aerial photos.

Next, a common legend of the dominant land use classes was constructed based on the individual legend of all maps (Herzog et al., 2001; Van Eetvelde et al., 2009; Gheyle et al., 2014). This uniform legend makes it possible to consistently analyze data from different periods and places. It smoothens the differences between the variety of topographic sources used, since the legend makes it possible to create general features such as land cover types and scales. A drawback of this method is the potential loss of information. For instance, the distinction between deciduous and coniferous forest was not made, and houses and gardens were not mapped individually.

19 land use classes could be defined for each time period (Table 2). In fact, the NGI maps show land cover (and not land use). This means that the time series and time depth maps explore the evolution of land cover between c. 1860 and 2000. However, in our cases, differences between 
land use and land cover were relatively small as the four villages were dominated by agricultural land use types. The selected categories of land cover were distinguishable on the aerial photos, which made it possible to use the proposed legend for all timeframes. The difficulty to differentiate between pasture and hay meadows on the (greyscale) photos was solved by putting them into one category (pasture). This was in agreement with the legends of the historical topographic maps, which brought the two land cover types together in one 'permanent grassland and hay meadow' category. The category pasture thus encompasses the land use for grazing and haying.

Based on this legend, for all maps, land use was digitized and stored as ArcMap features. For the visual presentation, however, we generalized some land use types. Both the different types of roads and water(ways) were visualized by one symbol. Smaller land use types (wetland, heath and recreation) were joined together in the category 'other'. The generalization of the legend enhanced the readability of the maps, while keeping it possible to analyze all of the 19 digitized land use classes. To avoid sliver polygons, the line structures are buffered for the average width of the corresponding land use types and subtracted from the polygons (Herzog et al., 2001).

\subsection{Data analyses}

In many studies on historic landscapes, techniques of the Historic Landscape Characterization (HLC) are applied to investigate landscape dynamics. Developed in the UK during the 1990's, HLC is a theoretical methodology aimed at a better understanding of historical depths present in the modern landscape (Karro et al., 2014; Van Eetvelde, 2006; Turner and Crow, 2010). The application of a consistent methodology for the processing of historical data makes it possible to investigate particular characteristics and changes of landscapes over time. A first concept of HLC which is frequently used are the time series (Petit and Lambin, 2002; Bender et al., 2005; Gheyle et al., 2014). In this study, a time series analysis of the digitized land use maps was performed to provide a first insight into the chronological sequence of land use over approx. 150 years. From these time series, basic metrics for each land use type are derived. In order to compare the data for all study sites, independent of the size of the municipality, surfaces of land use classes are presented as a percentage, whereas for linear landscape elements the density in $\mathrm{km} / \mathrm{km}^{2}$ is calculated. 
A second frequently used HLC concept is time depth. The time depth of an area describes the time period to which the actual elements in the landscape go back (Van Eetvelde, 2006; Antrop, 2007). Time depth maps do not map individual landscape features, but bundles them together based on their historical development and map them as areas (Turner and Crow, 2010). In this study, time depth maps were created for all four study sites. Because the occurrence of small errors during the georeferencing and digitizing processes, perfect vertical matches between the time periods are impossible. This is mainly the case for linear elements; hence, the calculation of the time depth of tree- and hedgerows is not executed. Time depth graphs are derived from the resulting time depth maps and show which fraction of the actual land use dates back to a certain time period.

Whilst the time series and time depth analysis mainly show the evolution of land use through time, landscape metrics may provide a more detailed insight into changes in landscape structure such as landscape fragmentation and diversity (e.g. Van Eetvelde and Antrop, 2009). Landscape metrics have been developed in the domain of the landscape ecology and are becoming increasingly popular in recent years (Gökyer, 2013; Antrop 2007; Herzog et al., 2001; Fjellstad et al., 2001). They are used to describe the landscape composition and configuration and characterize the landscape structure on three different levels: the individual patches, the land-use types and the entire landscape (Van Eetvelde and Antrop, 2009; Herzog et al., 2001). Whilst there are more than fifty different landscape metrics, many of them correlate with each other (Herzog et al., 2001). Here, three landscape metrics were calculated for each time period using the Patch Analyst tool in ArcMap 10.3. The first metric is the Mean Patch Size (MPS), which can be used to evaluate the fragmentation of the study area (Elkie et al., 1999; Van Eetvelde and Antrop, 2009). A decrease in MPS points towards an increase in landscape fragmentation, and vice versa (Gökyer, 2013). Second, the Mean Shape Index (MSI) is computed. This metric gives an indication of the complexity of the individual patches. The value of the Mean Shape Index equals one when all the patches are circular. The value increases when the shape of the patches is more irregular (Elkie et al., 1999). The Mean Shape Index is calculated as

$$
M S I=\frac{\sum_{i=1}^{m} \sum_{j=1}^{n}\left(\frac{0.25 p_{i j}}{a_{i j}}\right)}{n}
$$

where $\mathrm{p}_{\mathrm{ij}}$ refers to the perimeter of patch $\mathrm{ij}, \mathrm{a}_{\mathrm{ij}}$ to the area of patch $\mathrm{ij}, \mathrm{m}$ to the number of land use classes and $n$ to the number of patches. 
The Shannon's Diversity Index (SDI) refers to the diversity of patches in the area (Gökyer, 2013). It is a measure for the heterogeneity of the landscape, a combination of the diversity of land use classes and the frequency in which they occur (Van Eetvelde et al., 2009). The Shannon's Diversity Index equals zero when the landscape consists of only one single patch. The value increases when the number of patches rises and/or the proportional distribution of area among patch types becomes more equitable (Howard, 2005). The SDI is given by

$$
S D I=-\sum_{i=1}^{n}\left(P_{i} * \ln P_{i}\right)
$$

where $\mathrm{P}_{\mathrm{i}}$ refers to the proportion of the landscape with land use class I and $\mathrm{n}$ to the number of land use classes (Elkie et al., 1999).

HLC and metrics analyze landscape change with a bird's-eye view and in a quantitative manner. In order to receive the perceptions 'from below' a visibility analysis is needed. Indeed, changes in land use and landscape fragmentation or diversity may take place. The invariability of land use and landscape structures does indeed not exclude changes in landscape perception. Since no detailed digital elevation model is available for each time period, we constructed one for each period starting from the high-resolution (1m) LIDAR terrain model of Flanders from 2014. The DTM was adjusted by adding a mean height per land cover class: forest and tree lines $15 \mathrm{~m}$ (each tree standing at a distance of $10 \mathrm{~m}$ with open space between them), built-up areas $10 \mathrm{~m}$, cropland $0.5 \mathrm{~m}$, grassland $0.1 \mathrm{~m}$ and orchards $4 \mathrm{~m}$. Hedgerows, which mostly served as parcel borders, were given a height of $1.5 \mathrm{~m}$. Next, 50 points were randomly selected on the road network. For each point, the visibility was calculated at eye height $(1.7 \mathrm{~m})$. The visibility analysis assessed which proportion of the area in a radius of 100, 200, and $500 \mathrm{~m}$ was visible throughout time. This way, it can be estimated how transparent the landscape is and how it can be perceived from the road network at each time interval. Since the results of the different radii are showing the same trends, we will only present and discuss the results for the 200 m radius. 


\section{Results}

\subsection{Time series and time depth analysis}

Figure 5 shows the time series maps of Merkem, whilst time series maps of the other study sites can be found in appendices 1-3. Basic land use metrics (percentage of total surface are and density) derived from these time series maps are shown in Figure 6. Figure 7 shows the time depth maps and graphs of the four study areas and gives an indication of the historical dimension of the contemporary landscape. These data show that about 60 percent of the land use in Borlo-Buvingen has been unchanged for at least 150 years. Mainly parts of the open arable land around the village were preserved throughout time. The land use remained largely unchanged between 1860 and 1945, but underwent transformation from 1945 onwards. The time series of Merkem and Wijtschate shows similar trends: post-war landscapes were rehabilitated to their pre-war land use. In Wijtschate, about 48 percent of the mid- $19^{\text {th }}$ century land use has been preserved, mainly arable land and some plots of forest. Between 1914 and 1940,75 percent of the land use remained untouched. In Merkem, 38 percent of the $19^{\text {th }}$ century land use was maintained and 60 percent of the land use survived the tabula rasa of the Great War. In Liezele, only 29 percent of the contemporary land use dates from the mid-19 ${ }^{\text {th }}$ century or earlier. Before WWII the land use did not change much, with about 64 percent of the land use in 1903 being retained in 1940. This situation changed from 1945 onwards and even more during the 1960s and 1970s.

\subsection{Landscape metrics}

Figure 8 displays the evolution of the landscape metrics for the study areas providing a quantitative insight into the evolution of landscape structures. Merkem and Wijtschate both had an increase in MPS over the study period. This trend is, however, not linear. After WWII, the trend slowed down or even inverted, though it resumed afterwards. One can conclude that the landscape of Merkem and Wijtschate became less fragmented between the mid-19 ${ }^{\text {th }}$ century and the beginning of the 21th century. In addition, the shape of the individual patches was also becoming less complex as MSI decreased in this time period. SDI dropped with 0.2 to 0.3 , which signifies a small decrease of the landscape's heterogeneity throughout time. Liezele, on the other hand, became more fragmented between the mid- $19^{\text {th }}$ century and the beginning of the $21^{\text {th }}$ century. A small increase in mean patch size can be observed, whilst the mean shape 
index decreased. However, the Shannon's Diversity Index clearly has a rising trend. Thus, the landscape of Liezele became more heterogeneous between the mid- $19^{\text {th }}$ century and the beginning of the $21^{\text {th }}$ century. Borlo-Buvingen witnessed a decrease in mean patch size before 1960 , but a doubling during the latter half of the $20^{\text {th }}$ century. On the contrary, the Shannon's Diversity Index increased before 1960 and stabilized afterwards.

\subsection{Landscape visibility}

The visibility analyses presented in Figure 9 inform us about the ways in which local observers perceived the landscape changes in the four studied villages. A clear distinction can be made between the results for the villages in western Belgium (Merkem and Wijtschate) and those in northern and eastern Belgium (Liezele and Borlo-Buvingen). In the former cases, landscape visibility clearly increased over time. Around the middle of the $19^{\text {th }}$ century, observers in Merkem were able to see up to 50 percent of the surrounding landscape, with an average of c. 20 percent. In Wijtschate, this average was somewhat higher (c. 30 percent, and a maximum of 70 percent) due to its topographic position on a hill ridge. By 2000, average visibility had increased to more than 40 percent in both villages. This means that Merkem and Wijtschate witnessed a shift from a relatively closed to a more open landscape. The opposite evolution can be distinguished in Liezele and Borlo-Buvingen. In both villages, the visibility analyses show that landscape visibility around 1860-1870 was at a similar level as in Wijtschate. However, visibility in Borlo-Buvingen already declined in the course of $19^{\text {th }}$ century. This decline was continued into the $20^{\text {th }}$ century, but slowed down after the Second World War. In Liezele, the visibility of the landscape stabilized before 1945 , to decrease during the latter half of the $20^{\text {th }}$ century. In contrast with Merkem and Wijtschate, the landscapes in Liezele and BorloBuvingen thus gradually became more closed.

\section{Discussion}

\subsection{Landscape evolution: the long-term trend}

$19^{\text {th }}$-century rural Flanders was, among other things, characterized by a large degree of land fragmentation (see MPS in Figure 8). In all case study areas but Borlo-Buvingen, farmers cultivated small plots of land that were enclosed by hedges. These hedges, together with tree rows and dispersed patches of wood were the formative elements of a closed landscape, the 
bocage flamand. Woodlands, trees and hedgerows thus functioned as natural screens that hindered an open, panoramic view on the Flemish lowlands (this is also suggested by the visibility analysis in Figure 9). Although large forest complexes were absent in all villages but Merkem, where the Houthulst Forest covered the infertile sandy soils, the bocage flamand created the experience of the Flemish countryside as a particularly green area (Blanchard, 1906; Thoen, 2011). This perception was reinforced by the presence of small orchards around farmsteads, which were intended for personal use.

From the 1860s onwards, woodlands and linear greenery were increasingly under pressure (Heyde, 2014), and were gradually turned into arable land or pasture. In all villages but Borlo-Buvingen, orchards as well were in sharp decline before 1914. Arable land remained the principal land use type in all villages under study (see Figure 6). The geographical positioning of arable land and grassland was still very much dependent on the composition of the soil. In floodplain wetlands, grassland dominated the landscape. This was for example the case in Merkem - alongside the Yser River - and in Liezele. Arable land could be found on the most fertile soils of the village. This can clearly be seen in Merkem (Figure 5), where crops were cultivated on the loamy soils in the central areas of the village. In Wijtschate, fields and grassland alternated with small patches of woodland, especially on the steeper hillslopes around the village center. Due to their susceptibility to erosion, these slopes were found less suitable for arable farming and stockbreeding.

By the middle of the $20^{\text {th }}$ century, some long-term trends had now crystallized. In all four villages under study, arable land was increasingly converted into pasture. The small patches of woodland, which were dispersed across the municipal territories in the 19th century, became ever rarer in the course of the $20^{\text {th }}$ century (Figure 6). In Merkem, the vast Houthulst Forest had given way to farmland. This implies that the interconnectedness between soil composition and (agricultural) land cover was partially loosened during the $20^{\text {th }}$ century. Orchards disappeared in all villages but Borlo-Buvingen, which instead witnessed a significant growth of fruit meadows. This conclusion is at odds with the recent finding that in West Flanders 'orchards were massively replanted after the First World War' (Heyde, 2014: 37). ${ }^{1}$ The general disappearance of forests, woodland and trees and hedgerows further fostered the decreasing diversity of the rural landscapes across Flanders. While the Flemish countryside in the $19^{\text {th }}$ century was still characterized by a large degree of regional variation,

\footnotetext{
${ }^{1}$ This conclusion was made on a case study regarding the reconstruction of a castle domain near Ypres (Château d'Elzenwalle, Voormezele).
} 
this was less and less so in the $20^{\text {th }}$ century. Furthermore, it seems that agricultural land use was continued to be reshuffled during the interbellum (Dejongh and Vanhaute, 1999).

After the Second World War, rural landscapes were rationalized as the patches became larger in size and more homogeneous in form (see Figure 8). Moreover, a relatively rapid increase of grassland was observed that only slowed down during the last decade of the previous century (Figure 6). The area reserved for the plantation of forests stabilized, as was the total surface of arable land in all case studies but Liezele. Although hedges disappeared in all villages but Liezele, the openness of the landscape stabilized or decreased after 1945 (Figure 9). This is due to the presence of more orchards (in the case of Borlo-Buvingen) or residential buildings from that period onwards. This last evolution is particularly visible in Liezele that is situated in the heart of the Flemish Diamond, (i.e; the conurban area between the cities of Antwerp, Ghent, Brussels and Leuven; Albrechts, 1998). In spite of the small deviations between the selected case studies it is clear that in general, the landscape evolutions in all villages proceeded quite smoothly.

\subsection{The importance of the Great War}

The steady continuity that the rural landscapes displayed during the $19^{\text {th }}$ and $20^{\text {th }}$ centuries, begs the question of the importance of the Great War for the long-term developments of rural landscapes in Flanders. The previous analysis of long-term landscape evolutions first of all seems to run counter to common knowledge about the destructive consequences of the Great War. Between 1914 and 1918, approximately four percent of Belgium's farmland was transformed into a moonscape. This area was entirely concentrated on a small strip between the North Sea coast and the Franco-Belgian border near Ypres. At least 80,000 houses were destroyed, of which more than half were situated in the province of West Flanders (Smets 1926; Verwilghen, 1923). The perceived continuity in Belgium is even more surprising when compared to the deficiency of post-war recovery processes in France. At the end of the 1920s still 50,000 ha of land in Northern France was defined as zone rouge or 'red zone'. These territories, which equaled more than half of the devastated regions in Belgium, were deemed too devastated to be cleaned and levelled. Being considered 'lost for agriculture', these grounds were expropriated by the French government and were eventually forested or reconfigured as places of memory (Clout, 1996: 261-272; Marival, 2005: 383-392). 
Secondly, the research results appear to be at odds with recent studies about the militarization of the landscape in western Belgium between 1914 and 1918. Detailed analyses of WWI aerial photographs indicate that the Ypres salient landscape and the Yser floodplains were strewn with military infrastructure (Stichelbaut et al., 2017a; Stichelbaut, 2011). Although the Belgian government and local inhabitants tried to erase the traces of war during the 1920s, many relics are still present in today's landscape (Van den Berghe et al., 2018). This is of course the case for commemorative monuments, military cemeteries, and remaining pillboxes. Military constructions, such as trenches, but also some craters are still visible at surface level, particularly in wooded areas (Gheyle et al., 2014; Verboven, 2014; Meire, 2003). These remaining traces contributed to the slight decrease of farmland in the front region during the interwar years. However, these directly observable elements only represent a fraction of the war heritage that has been preserved. Non-invasive archaeological research and high-resolution laser scanning have revealed that many small-scale features are still preserved in the West Flemish countryside, above as well as beneath surface level (Stichelbaut et al., 2017b; Gheyle et al., 2018).

Although initial ideas to create a Belgian 'red zone' were disbanded during the course of 1919, the agricultural acreage in West Flanders never fully recovered from the wartime destructions. Between 1910 and 1929, the area in this province reserved for agriculture dropped by almost three percent, from 308,884 to 299,925 ha (NIS 1910, 1929; Blomme, 1992: 48 and 229). ${ }^{2}$ A first explanation for this loss of agricultural land can be found in the decreasing importance of the primary sector in the Belgian economy. Secondly, the construction of military cemeteries and war memorials, as well as the non-recovery of small patches of land also played its role. However, this loss was sometimes compensated by the clearing of forests (Tallier, 2004: 566). This practice can be observed in Merkem, where the Houthulst Forest was dramatically deforested in the aftermath of the Great War. Both the Belgian government and the local landowners regarded the destruction of the forest as an opportunity to revert the marginal sandy soils into agricultural land. This can be seen as an income strategy for landowners. At the same time, the central government believed that the enlargement of the agricultural acreage would benefit the output volume of the Belgian primary sector in a time of food shortages (Fleissig and Whitney, 2015).

\footnotetext{
2 These numbers are calculated on the basis of the agricultural censuses of 1910 and 1929 and the correction coefficients proposed in the work of Blomme (1.059 for 1910 and 1.099 for 1929). At the same time, total agricultural acreage in Belgium decreased from 2.07 million ha to 1.96 million ha.
} 
In the former front region, the disappearance of woodland fostered the evolution from a closed bocage landscape to a countryside with a more open view. The results of the visibility analysis for Merkem and Wijtschate clearly indicate this. However, the increased openness of the landscape could not only be traced back to processes of deforestation. The decision of farmers to replace natural fencing by barbed wire also contributed to the fact that contemporary observers perceived the West Flemish landscape differently. Also in Liezele, a moderate decline of hedges and tree rows could be detected. On the short run, the Great War also influenced the configuration of the landscapes under study (Figure 8). The calculated MSI indicate that in all selected villages, and in Merkem and Wijtschate in particular, the form of patches became less complex (Elkie et al., 1999). In the context of an agricultural environment, this means that in the aftermath of the Great War farmers reorganized their farmland on a more rational basis, for example through the concentration of pasture and arable plots. In contrast with the French case (Clout, 1996: 259), no policies for land resettlement were initiated during the post-war reconstruction process. The Belgian government mainly limited its own intervention to the distribution of financial means, partially with war compensations it had received from Germany (Cornilly et al., 2009).

\subsection{Long-term developments and the reconstruction of the rural landscape}

Although the Great War is still visible in Flanders fields, the wartime devastations did not have a significant effect on the structure and land use in the villages under study. The post-war reconstruction process mainly corresponded to - but also accelerated - driving forces that had already shaped (and reshaped) Belgium's rural landscapes before 1914. Two driving forces in particular help to explain how our case study villages changed from the second half of the $19^{\text {th }}$ century onwards: agricultural transformations and demographic evolutions. With regard to Belgian agriculture, an evolution from arable farming aimed at the food security of the population, towards more market-oriented forms of production based on livestock breeding occurred from the late $19^{\text {th }}$ century onwards. This reorientation was inspired by the import of cheap grains from overseas areas, primarily the Americas (Blomme, 1992; Segers et al., 2004). The growing concentration of Belgian farmers on stockbreeding translated into a spatial redistribution of the farmland in the case study villages. Especially in Merkem and Wijtschate, there has been a steady increase of pasture during the course of the investigated one and a half century. Besides the aforementioned economic factors, the relatively sharp growth of pasture 
in Merkem after the Great War can be explained by the conversion of large stretches of Houthulst Forest in the east of the village.

On the other hand, the arable surface in Merkem and Wijtschate continued to expand - albeit slightly - between 1860 and 1914, as part of a more general expansion of agricultural land in Belgium until the early $20^{\text {th }}$ century (Blomme, 1992: 229). ${ }^{3}$ During the interbellum, however, arable land in these villages started to decrease slightly, a trend that had already started in Borlo-Buvingen before the Great War. While in regions less suitable for fruit growing orchards tended to lose their importance from the last quarter of the $19^{\text {th }}$ century onwards, farmers in the fertile loam regions in central and eastern Belgium (Hesbaye region) adopted income strategies that combined fruit growing and livestock farming (Jacobs, 1997). This evolution clearly left its marks on the landscape of Borlo-Buvingen. In all villages, a more profound decline of arable land took off after 1945. This evolution was manifest in Liezele, which is situated in the urban area between Antwerp and Brussels and where agricultural land was increasingly employed for residential use. The fragmentation of land in this village paradoxically increased the diversity of the landscape, as was measured with SDI (Figure 8).

In order to meet international competition, Belgian farmers did not only shift towards horticulture and stockbreeding. They also adopted measures to increase arable productivity (Blomme, 1992: 153-160). Firstly, this meant that more qualitative artificial fertilizers and commercial feeds were used. Secondly, mechanical devices were introduced to improve land productivity and absorb the growing shortage (and higher wages) farm labor. However, Blomme stated that the 'mechanization of agriculture remained a rather marginal phenomenon until 1950' (1992: 234). The introduction of tractors and other motorized farm equipment was especially hampered by the small scale of enterprises. Until the second half of the $20^{\text {th }}$ century, the average farm size fluctuated between six and seven ha. At that time, small-scale farming was considered as a valuable and more suitable alternative for the Belgian agricultural sector. Little investments had to be made in agricultural machinery and wage labor (Van Molle, 1989: 84-7). An increase in scale only occurred after the Second World War as the farm size doubled between 1950 and 1980 (Blomme, 1992: 229).

Since the motorization of Belgian agriculture was still in its infancy during the interbellum, farmers felt no need for land resettlements during the reconstruction process. Moreover, stockbreeding and horticulture, two branches of agriculture that were of increasing importance,

\footnotetext{
${ }^{3}$ In 1910, Belgian agricultural acreage reached a maximum of 2.07 million hectares.
} 
were less space-consuming than arable farming. Thirdly, the Belgian government did not encourage the redistribution of landed property, since it involved highly complex and for some proprietors emotionally charged processes of land exchange (Molema and van den Brink, 2009). ${ }^{4}$ The MSI in Figure 8 shows how the size of patches of farmland does not increase significantly before WWII. It took the Belgian government until the 1960s - when the tractor started to replace draught animals on the field (Auderset and Moser, 2016) - to execute the first land resettlement schemes in the fertile Hesbaye region, and more specifically in BorloBuvingen. The metrics (MPS and MSI) for this village clearly indicate that the local landscape structures were rationalized quite dramatically during the post-war period. Because this study was not executed on the level of single parcels, further research should nevertheless be done to investigate the structural evolution of individual fields.

Demographic changes also influenced land use in the Belgian countryside. Between 1866 and 2000, the total population of Belgium more than doubled (Statbel, 2018). This did not only result in an increased urbanization, but also in higher population densities in peripheral regions. In the western part of the country, the rural villages of Merkem and Wijtschate grew with 7 and 10 percent respectively between 1866 and 1910. The population of Borlo-Buvingen and Liezele increased with respectively 24 and 53 percent during the same period. The population growth in Liezele was a consequence of suburbanization processes and (particularly after WWII) its geographical position in the Flemish Diamond, consisting of the metropolitan centers of Antwerp, Brussels, Ghent and Leuven. Borlo-Buvingen was not situated in one of those metropolitan areas, but owed its strong population growth to its fertile loamy soil (Ceunen, 2011: 36). In addition, the improvement of transport networks made it possible for rural dwellers to commute, and hence to work in the city while living in the countryside (Antrop, 2004: 10; De Block and Polasky, 2011). By the end of the $19^{\text {th }}$ century, Belgium had one of the densest railway networks across the world (De Decker, 2011: 1638-9).

The increasing population did not bring about a spectacular expansion of the built-up surface. In all case study villages, the space devoted to residential housing was limited to five percent of total area and a maximum one percentage point increase between 1866 and 1914 (in Merkem). Although the Great War negatively affected population figures (except for BorloBuvingen), the built-up areas in all villages slightly increased during the interbellum. This was mainly due to the extension of the village centers. After WWII, the land used for buildings

\footnotetext{
${ }^{4}$ Marijn Molema and Adri van den Brink argued that in the Netherlands, proposals for land resettlement were initially debunked by traditional views of farmers and their emotional attachment to ancestral grounds.
} 
expanded more rapidly. This is striking, since the population growth in Belgium started to stagnate or even decrease during the last quarter of the $20^{\text {th }}$ century. This paradox corresponds to the general development of building lots, which became ever larger to allow for comfortable housing and private gardens (Van Hecke et al., 2010: 36). At the same time, a second demographic transition resulted in the decrease of mean family size, which urged for new housing in towns and villages (Lesthaeghe, 2011). The post-WWII expansion of the built-up area visible in the time series is directly linked to these evolutions, as well as to the growth of purchasing power and state policies that were aimed at the (unplanned) building of workingclass and rural houses (De Taeye Law of 1953, Floré, 2010).

\section{Conclusion}

Several recent geographic and archeological studies have uncovered the remaining traces of war in today's landscape (e.g. Stichelbaut, 2017a; Gheyle, 2018). This study, however, focused on the Great War's impact on the rural landscape on the long run. For four selected villages, a detailed analysis of landscape change between 1860 and 2000 was made based on topographic maps and military aerial photography of both world wars. This analysis revealed that the largescale destructions of the Great War had no profound effect on the evolutions of land use and landscape structures on the long run. Rather than a period of discontinuity, the Great War can be regarded as a catalyst of landscape transformations that had already taken off before 1914 .

Both in Merkem and Wijtschate, underlying economic and demographic driving forces deeply affected post-war reconstruction processes. While the militarization of the landscape between 1914 and 1918 indeed left its marks on the post-war landscape through concrete shelters, trenches, cemeteries and other military infrastructure, the devastated buildings and disturbed agricultural acreage were rapidly restored during the first years after the Armistice. With regard to land use, landowners and local farmers anticipated evolutions in agriculture that had already started to reshape the countryside since the late $19^{\text {th }}$ century. The shift from arable farming towards stockbreeding was met with an increase of pasture already before 1914 and even more so during the interbellum. As a result, the share of arable land decreased in the same period. These evolutions continued during the second half of the $20^{\text {th }}$ century. However, post-war reconstruction was not only a story of steady continuity. The Great War did hasten the disappearance of the bocage landscape in western Belgium. Whilst the density of hedgerows in the landscape, especially those bordering meadows, were already in decline before the Great 
War, these were almost completely removed following this cataclysmic event. As such, the Great War accelerated the creation of a more open landscape in Merkem and Wijtschate. As far as landscape structures are concerned, shapes of agricultural and building plots became less complex, which was also consistent with long-term evolutions.

The integration of two villages that suffered less or no wartime destructions, Liezele and BorloBuvingen, allowed us to compare landscape transformations in the former front zone and other regions in Flanders, the northern part of Belgium. The landscapes in these villages witnessed similar evolutions as in Merkem and Wijtschate. Pasture increased and arable land decreased over time. Built-up areas expanded, particularly in Liezele that was situated in the highly urbanized region between Antwerp and Brussels. Hedges and tree rows gradually (but not completely) disappeared, although this did not result in an increased visibility of the landscape. The expansion of the village center in Liezele and orchards in Borlo-Buvingen hindered a more open view on the landscape. Thus, the comparative analysis indicates that long-term landscape changes in Merkem and Wijtschate would not have been significantly different without the impact of the Great War. The fact that these continuities have been underplayed is the result of the dominant representation of the former front region as a military landscape, strengthened by a deliberate choice to preserve and manage the elements that still refer to the horrors of the Great War, rather than a landscape of reconstruction (Vandael, et al., 2016).

\section{Bibliography}

Albrechts, L. (1998). The Flemish Diamond: Precious gem and virgin area. European Planning Studies 6, no. 4, 411-424.

Antrop, M. (2000). Background Concepts for Integrated Landscape Analysis. Agriculture Ecosystems \& Environment 77, no. 1-2, 17-28.

Antrop, M. (2004). Landscape change and the urbanization process in Europe. Landscape and Urban Planning 67, no. 1-2 (2004), 9-26.

Antrop, M. (2005). Why landscapes of the past are important for the future. Landscape and Urban Planning 70, no. 1-2, 21-34.

Antrop, M. (2007). Perspectieven op het landschap: achtergronden om landschappen te lezen en te begrijpen. Ghent: Academia Press.

Auderset J., \& Moser, P. (2016). Mechanisation and motorization. Natural resources, knowledge, politics and technology in $19^{\text {th }}$ - and $20^{\text {th }}$-century agriculture. In C. Martiin, J. 
Pan-Montojo, \& P. Brassley (eds.), Agriculture in capitalist Europe, 1945-1960: From food shortages to food surpluses (pp. 145-164). London: Routledge.

Bender, O., et al. (2005). Using GIS to analyse long-term cultural landscape change in Southern Germany. Landscape and Urban Planning, 70, no. 1-2, 111-125.

Bicik, I., et al. (2015). Land Use Changes in the Czech Republic 1845-2010: Socio-Economic Driving Forces. Heidelberg: Springer.

Blanchard, R. (1906). La Flandre: étude Géographique De La Plaine Flamande En France, Belgique Et Hollande. Paris: Colin.

Blomme, J. (1992). The Economic Development of Belgian Agriculture: 1880-1980: A Quantitative and Qualitative Analysis. Studies in Belgian Economic History 3. Brussels: Koninklijke Academie Voor Wetenschappen, Letteren En Schone Kunsten Van België. Comité Economische Geschiedenis.

Bourgeois, G. (2017). http://www.geertbourgeois.be/nieuws/negen-mijnkratersites-uit-wo-ivoorlopig-beschermd. Accessed 29 August 2017.

Braudel, F. (1949). La Méditerranée et le Monde Méditerranéen à l'époque de Philippe II. Paris: Colin.

Bürgi, M., Hersperger, A., \& Schneeberger, N. (2004). Driving forces of landscape change current and new directions. Landscape Ecology, 19, no. 8, 857-868.

Ceunen, N. (2011). Het Landschap Vertelt: Haspengouw \& Voeren, de mens vormt zijn land. Kortessem: Regionaal Landschap Haspengouw en Voeren.

Chielens, P., Dendooven, D., \& Decoodt, H. (2006). De Laatste Getuige: Het Oorlogslandschap Van De Westhoek. Tielt: Lannoo.

Claeys, D. (2017). World War I and the reconstruction of rural landscapes in Belgium and France: a historiographical essay. Agricultural History Review, 65, no. 1, 108-129.

Clout, H. (1996). After the Ruins: Restoring the Countryside of Northern France after the Great War. Exeter: University of Exeter Press.

Cornilly, J., De Caigny, S., \& Vandermarliere, K. (eds). (2009). Bouwen aan wederopbouw: architectuur in de Westhoek 1914/2050. Ieper: Erfgoedcel CO7.

De Block, G., \& Polasky, J. (2011). Light railways and the rural-urban continuum: technology, space and society in late-nineteenth-century Belgium. Journal of Historical Geography, 37, no. 3, 312-328.

De Decker, P. (2011). "Understanding housing sprawl: the case of Flanders, Belgium." Environment and Planning A 43, 1634-1654.

Dejongh, G., \& Vanhaute, E. (1999). Arable productivity in Belgian agriculture, c. 1800-c. 1950. In B. Van Bavel, \& E. Thoen (eds.), Land Productivity and Agro-systems in the North 
Sea Area (Middle Ages - 20th Century): Elements for Comparison (pp. 65-84). CORN Publication Series 2. Turnhout: Brepols, 1999.

De Vos, L., Simoens, T., Warnier, D., \& Bostyn, F. (2014). 14-18: Oorlog in België. Leuven: Davidsfonds.

Dewilde, M., Stichelbaut, B., Van Hollebeeke, Y., Verboven, H., \& Wyffels, F. (2014). Bellewaarde en zijn turbulente oorlogsverleden. $M \& L$ : Monumenten, Landschappen en Archeologie, 33, no. 3, 30-47.

Elkie, P., Rempel, R., \& Carr, A. (1999). Patch Analyst User's Manual: A Tool for Quantifying Landscape Structure. Thunder Bay: Queen's Printer for Ontario.

Fjellstad, W., Dramstad, W., Strand, G. H., \& Fry, G. (2001). Heterogeneity as a measure of spatial pattern for monitoring agricultural landscapes. Norwegian Journal of Geography, 55, no. 2, 71-76.

Flanders Heritage Agency. (2017). Erfgoed van de Eerste Wereldoorlog als UNESCO Werelderfgoed. Brussels: Agentschap Onroerend Erfgoed.

Fleissig, A., \& Whitney, G. (2015). Belgium relief fund, post war food shortages and the "True" cost of living. Explorations in Economic History, 58, 93-106.

Flemish Government. (2011). "100 Jaar Groote Oorlog in Vlaanderen.”

Floré, F. (2010). Lessen in goed wonen: woonvoorlichting in België 1945-1958. Leuven: Leuven University Press.

Geertsema, M., Highland, L., and Vaugeouis, L. (2009). Environmental Impact of Landslides. In K. Sassa, \& P. Canuti (eds.), Landslides - Disaster Risk Reduction (pp. 589607). Berlin/Heidelberg: Springer, 2009.

Gheyle, W., et al. (2014). Integrating Archaeology and Landscape Analysis for the Cultural Heritage Management of a World War I Militarised Landscape: the German Field Defences in Antwerp. Landscape Research, 39, no. 5, 502-522.

Gheyle, W., et al. (2016). Historical Aerial Photography and Multi-receiver EMI Soil Sensing, Complementing Techniques for the Study of a Great War Conflict Landscape. Archaeological Prospection, 23, 149-164.

Gheyle, W., et al. (2018). Scratching the surface of war. Airborne laser scans of the Great War conflict landscape in Flanders (Belgium). Applied Geography, 90, 55-68.

Gils, R., \& Schokkaert, L. (1990). Het Fort van Liezele. Puurs: Vriendenkring Fort van Liezele.

Gökyer, E. (2013). Understanding Landscape Structure Using Landscape Metrics. In M. Özyavuz (ed.). Advances in Landscape Architecture (pp. 663-676). S.1., InTech. 
Herzog, F., Lausch, A., Müller, E., Thulke, H. H., Steinhardt, U., \& Lehmann, S. (2001). Landscape Metrics for Assessment of Landscape Destruction and

Rehabilitation. Environmental Management, 27, no. 1, 91-107.

Heyde, S. (2014). Het herstel van het bocagelandschap in de zuidelijke Westhoek na de Eerste Wereldoorlog. M\&L: Monumenten, Landschappen en Archeologie, 33, no. 1, 28-41.

Hostert, P., et al. (2011). Rapid land use change after socio-economic disturbances: the collapse of the Soviet Union versus Chernobyl. Environmental Research Letters, 6, no. 4, 18 .

Howard, N. K. (2005). Multiscale analysis of landscape data sets from northern Ghana: Wavelets and pattern metrics. Göttingen: Cuvillier.

Hupy, J., \& Schaetzl, R. (2008). Soil development on the WWI battlefield of Verdun, France. Geoderma, 145, no. 1-2, 37-49.

Jacobs, V. (1997). Limburgs-Haspengouw: een fruitstreek met traditie. Borgloon: Fruitstreekmuseum.

Karro, K., Mägi, M., \& Palang, H. (2014). Studying Past Landscapes: Lived, Reconstructed and Animated. Living Reviews in Landscape Research, 8, no. 1, 5-18.

Khan, M., et al. (2015). Natural Disasters and Land-use/land-cover Change in the Southwest Coastal Areas of Bangladesh. Regional Environmental Change, 15, no. 2, 241-250.

Lambin, E., \& Geist, H., (eds.). (2006). Land-Use and Land-Cover Change: Local Processes and Global Impacts. Berlin/Heidelberg: Springer.

Lesthaeghe, R. (2011). The 'second demographic transition': a conceptual map for the understanding of late modern demographic developments in fertility and family formation. Historical Social Research, 36, no. 2, 179-218.

Marival, G. (2005). Agriculteurs et élus locaux contre la zone rouge (1919-1929). La première bataille de l'après-guerre sur le Chemin des Dames. In R. Cazals, E. Picard, \& D. Rolland (eds.), La Grande Guerre, pratiques et expériences (pp. 383-392). Toulouse: Privat.

Meire, J. (2003). De stilte van de Salient: de herinnering aan de Eerste Wereldoorlog rond Ieper. Tielt: Lannoo.

Molema, M., \& van den Brink, A. (2009). In naam van het algemeen belang. De ontstaansgeschiedenis van de ruilverkaveling als instrument voor inrichting van het platteland. Tijdschrift voor Geschiedenis, 122, no. 1, 72-85.

Nationaal Instituut voor de Statistiek. (1910). Landbouw: telling op 31 december 1910. Brussels: NIS.

Nationaal Instituut voor de Statistiek. (1929). Landbouw: telling op 31 december 1929. Brussels: NIS. 
Petit, C., \& Lambin, E. (2002). Long-term Land-cover Changes in the Belgian Ardennes (1775-1929): Model-based Reconstruction vs. Historical Maps. Global Change Biology, 8, no. 7, 616-630.

Saey, T., Stichelbaut, B., Bourgeois, J., Van Eetvelde, V., \& Van Meirvenne, M. (2013). An Interdisciplinary Non-Invasive Approach to Landscape Archaeology of the Great War. Archaeological Prospection, 20, 39-44.

Segers, Y., Van Molle, L., \& Vanpaemel, G. (2004). In de greep van de vooruitgang, 18801950. In Y. Segers, \& L. Van Molle (eds.), Leven van het land. Boeren in Belgie,, 1750-2000 (pp. 49-109). Leuven: Davidsfonds.

Smets, G. (1926). Les régions dévastées et la réparation des dommages de guerre. In E. Mahaim (ed.), La Belgique Restaurée: étude sociologique (pp. 71-139). Brussels: Lamertin.

Statbel. De volkstellingen in België sinds 1830. (2018). https://statbel.fgov.be/nl/overstatbel/wat-doen-we/volkstellingen-census. Accessed 16 May 2018.

Stichelbaut, B. (2009). World War One aerial photography: An archaeological perspective. $\mathrm{PhD}$ diss., Ghent University.

Stichelbaut, B. (2011). The first thirty kilometres of the western front 1914-1918: an aerial archaeological approach with historical remote sensing data. Archaeological Prospection, 18, no. $1,57-66$.

Stichelbaut, B., \& Chielens, P. (2013). The Great War Seen from the Air: In Flanders Fields, 1914 - 1918. New Haven: Yale University Press.

Stichelbaut, B., et al. (2017a). The Ypres Salient 1914-1918: historical aerial photography and the landscape of war. Antiquity, 91, no. 355, 235-49.

Stichelbaut, B., et al. (2017b). Non-invasive research of tunneling heritage in the Ypres Salient (1914-1918) - research of the Tor Top tunnel system. Journal of Cultural Heritage, 26, 109-117.

Tallier, P. A. (2004). Forêts Et Propriétaires Forestiers En Belgique De La Fin Du XVIIIe Siècle à 1914: Histoire De L'évolution De La Superficie Forestière, Des Peuplements, Des Techniques Sylvicoles Et Des Débouchés Offerts Aux Produits Ligneux. Académie Royale De Belgique. Classe Des Lettres. Mémoires. Collection In-8. 3th Series 32. Brussels: Royal Academy of Belgium.

Thoen, E. (2011). La géographie historique, discipline en crise: plaidoyer pour une nouvelle approche. Un regard subjectif sur l'étude historique du paysage. Revue belge de philologie et d'histoire, 89, no. 2, 803-819.

Turner, S., \& Crow, J. (2010). Unlocking Historic Landscapes in the Eastern Mediterranean: Two Pilot Studies Using Historic Landscape Characterisation. Antiquity, 84, 216-229.

Vandael, L., et al. (2016). The heritage of 'Flanders Fields': Research, protection, management and commemoration of World War I landscapes in Flanders (Belgium). In K. 
Reeves et al. (eds.), Battlefield Events: Landscape, Commemoration and Heritage (pp. 95108). Abingdon/New York: Routledge.

Van den Berghe, H., et al. (2018). Using the past to indicate the possible presence of relics in the present-day landscape: the Western Front of the Great War in Belgium. Landscape Research, 1-22.

Van Eetvelde, V. (2006). Van geografische strekenkaart tot landschapsdatabank. Gebruik van GIS, informatietheorie en landschapsmetrieken voor het karakteriseren van landschappen, toegepast op België. PhD diss., Ghent University.

Van Eetvelde, V., \& Antrop, M. (2009). Indicators for Assessing Changing Landscape Character of Cultural Landscapes in Flanders (Belgium). Land Use Policy, 27, no. 4, 901910.

Van Hecke, E., et al. (2010). Atlas van België: landschap, platteland en landbouw. Ghent: Academia Press.

Van Molle, L. (1989). Katholieken en landbouw: landbouwpolitiek in België, 1884-1914. Leuven: Leuven University Press.

Verboven, H. (2014). De Westhoek ondermijnd (1914-18). M\&L: Monumenten, Landschappen en Archeologie, 33, no. 1, 6-27.

Verwilghen, R. (1923). De verrijzenis van verwoest Vlaanderen." Henri Brutsaert, Léon Boereboom, and Raphaël Verwilghen (eds.), Nieuw-Vlaanderen (pp. 61-86). Antwerp: Kiliaan.

Vrielinck, S. (2000). De territoriale indeling van België (1795-1963): Bestuursgeografisch en statistisch repertorium van de gemeenten en de supracommunale eenheden (administratief en gerechtelijk), met de officiële uitslagen van de volkstellingen. Leuven: Leuven University Press.

Westing, A. (2013). Arthur H. Westing: Pioneer in the Environmental Impact of War. Heidelberg: Springer. 


\section{Figures}
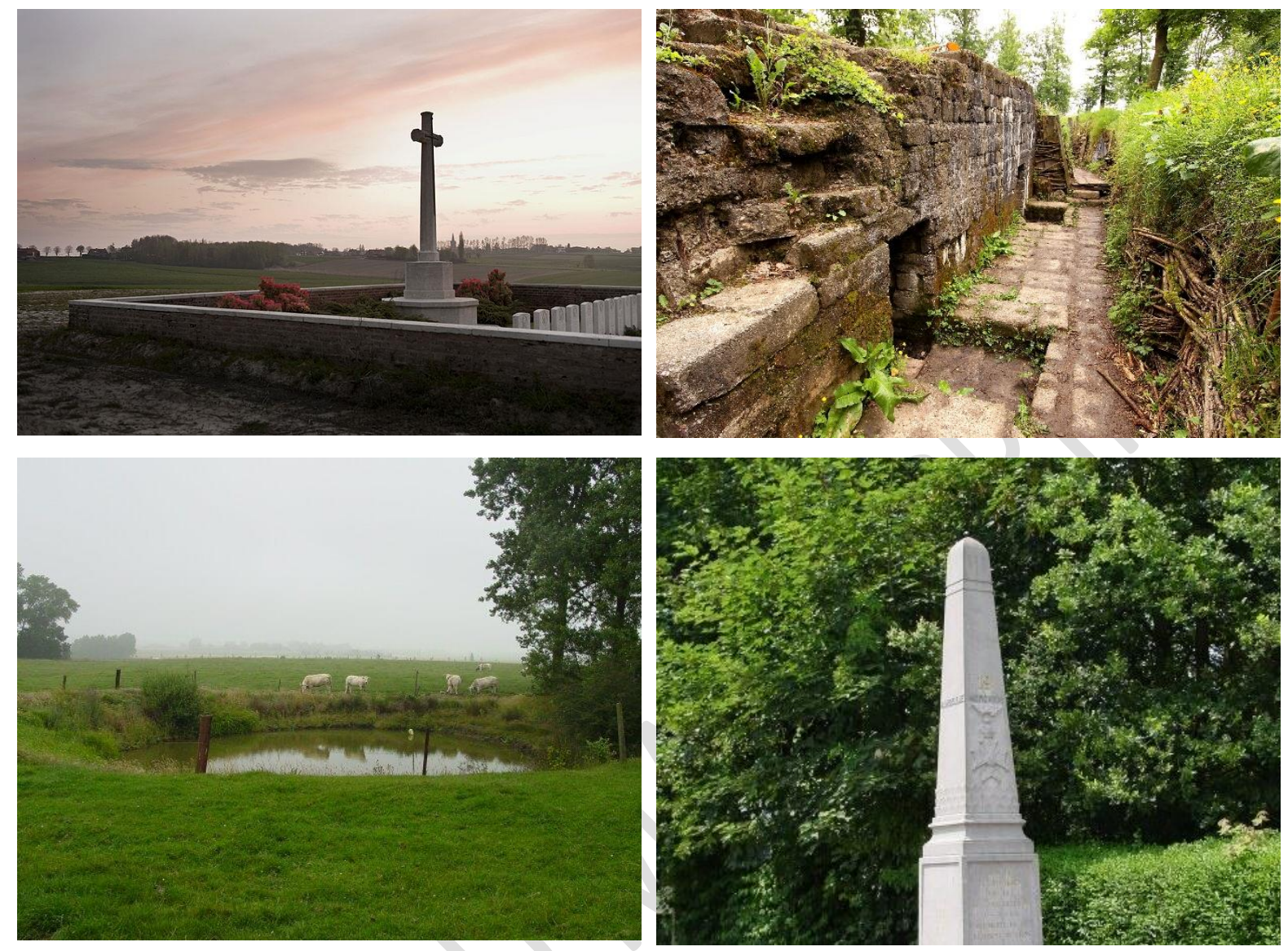

Figure 1: Remaining traces of the First World War in today's landscape. Clockwise: Lone Tree Cemetery Wijtschate, German concrete shelter near Wijtschate, Mine crater at Bellewaerde Rigde Ypres, Belgian war monument in Merkem (Sources: Wikimedia Commons and Flanders Heritage Agency). 


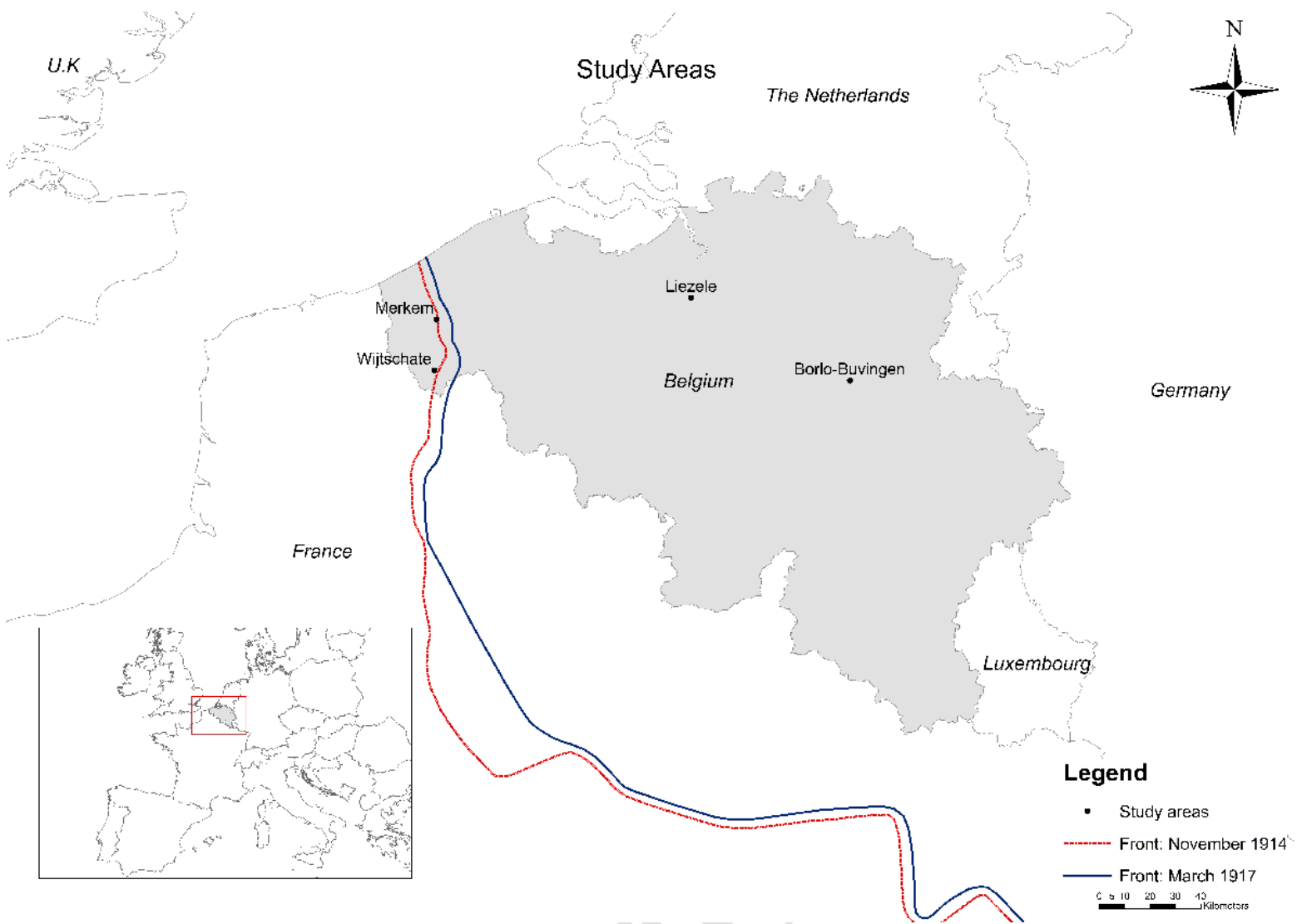

Figure 2: Location of the study areas in Flanders, Belgium and indication of the frontline during the Great War. 

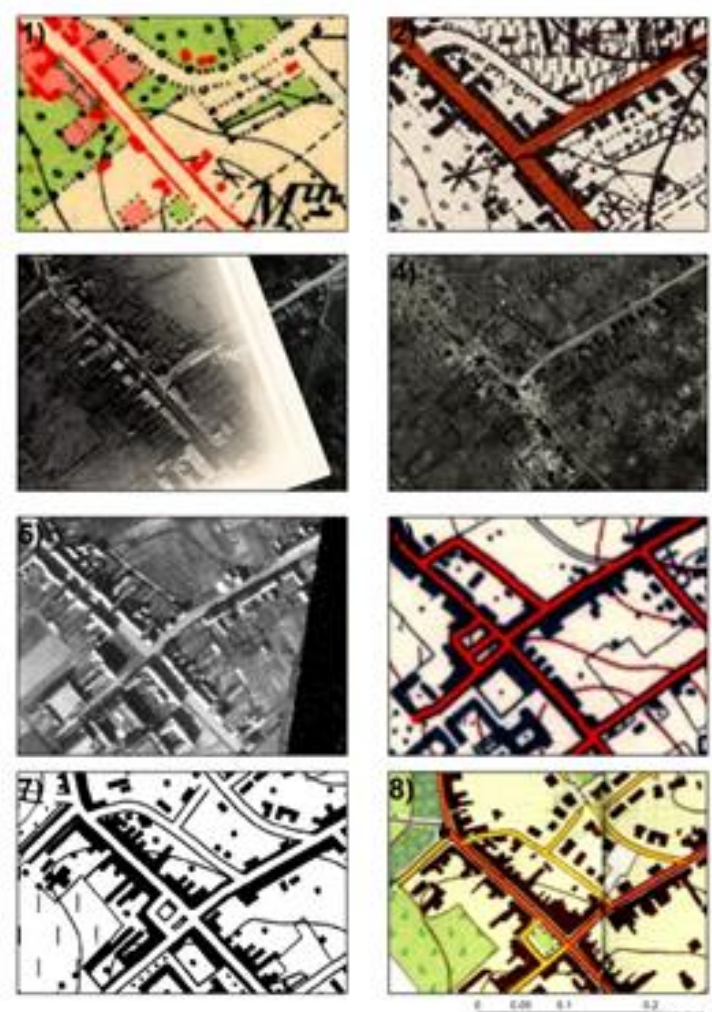

Figure 3: Chronology of the spatial data collected for the central part of Merkem

(five timeframes before 1914 and after 1945 include topographic maps; three timeframes - c. 1914 , c. 1918 , c. 1940 - include aerial photographs). 


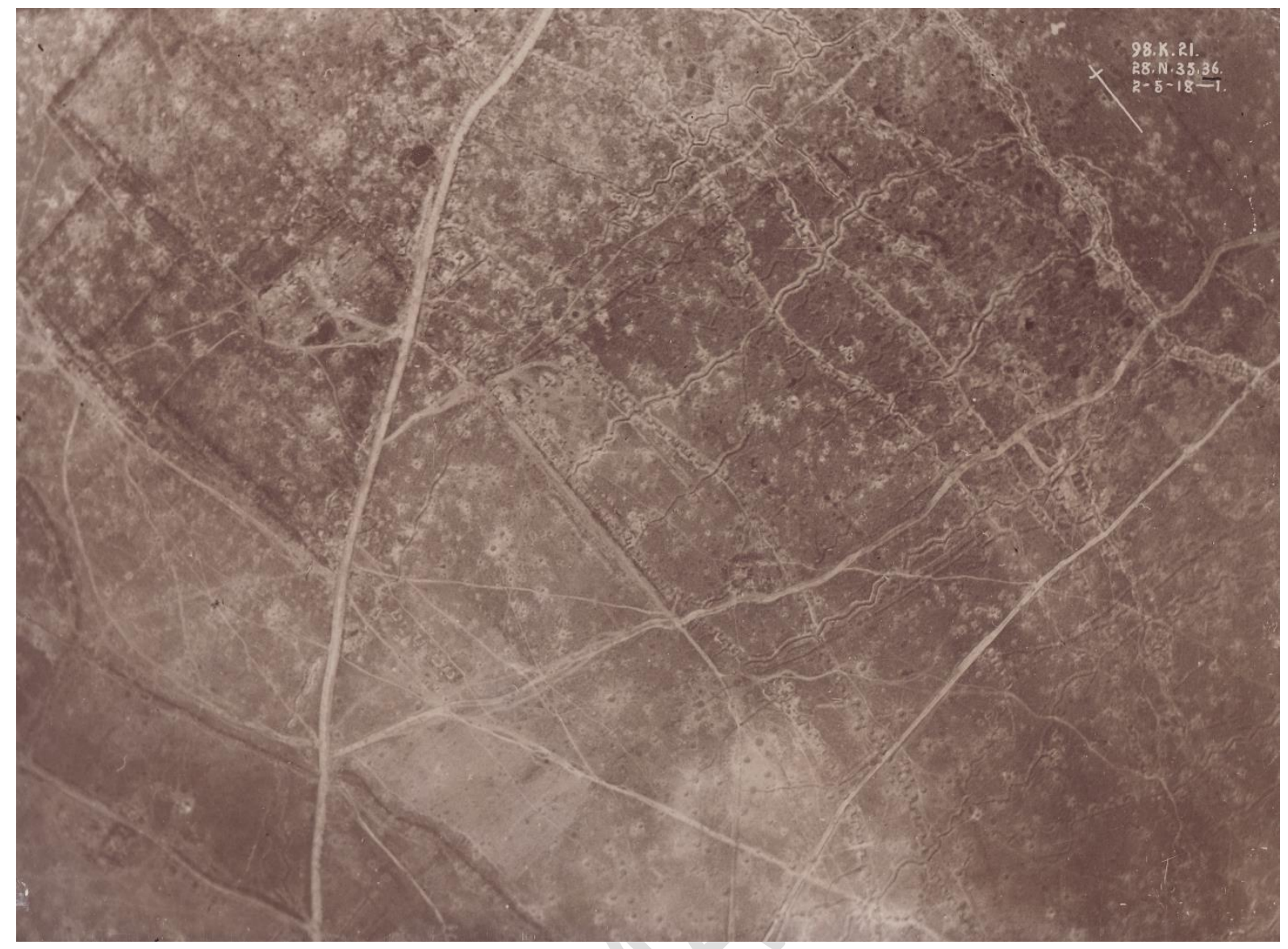

Figure 4: Degraded landscape of Wijtschate, 2 May 1918. Trenches and shell holes are clearly visible. Roads are one of the few pre-war elements that can still be distinguished. (Source: Australian War Memorial) 


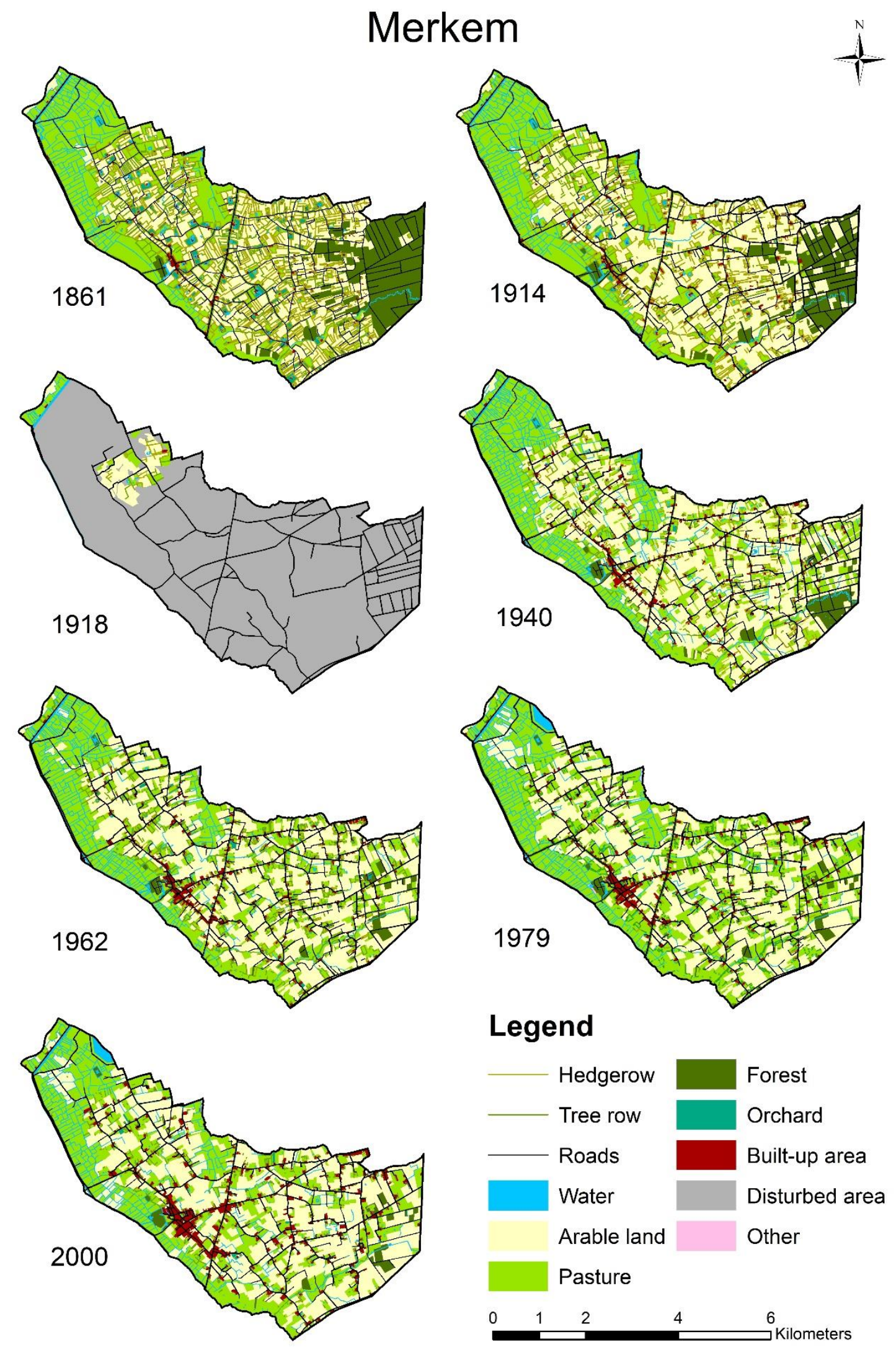

Figure 5: Time series maps of Merkem (1861-2000) 


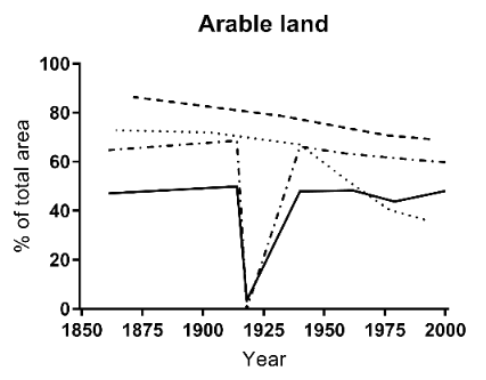

- Merkem

..- Wijtschate

.... Liezele

-.. Borlo

Forest



- Merkem

-.. Wijtschate

... Liezele

-.. Borlo

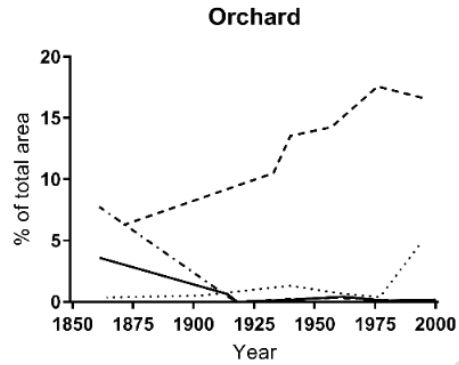

- Merkem

... Wijtschate

.... Liezele

-.. Borlo

Roads

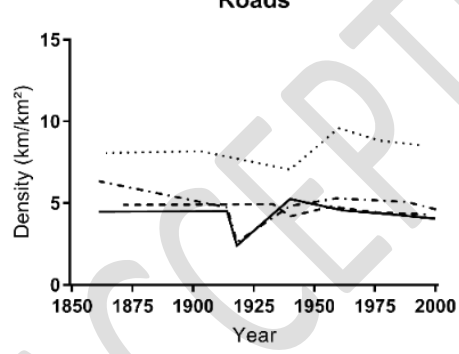

- Merkem

-. Wijtschate

... Liezele

-.. Borlo

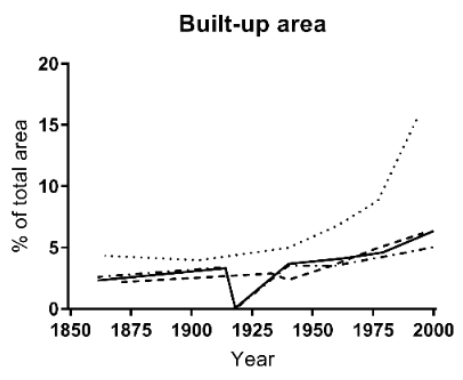

- Merkem

.. Wijtschate

.... Liezele

-.. Borlo

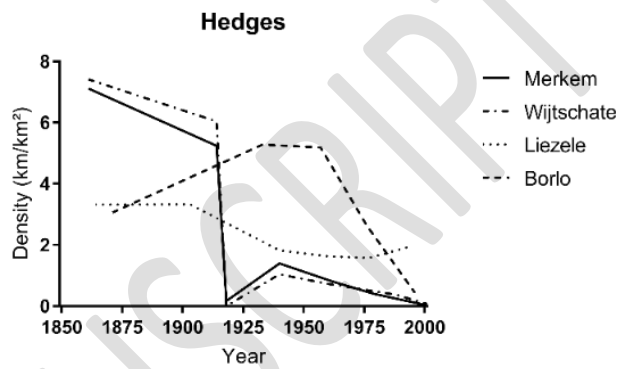

Pasture

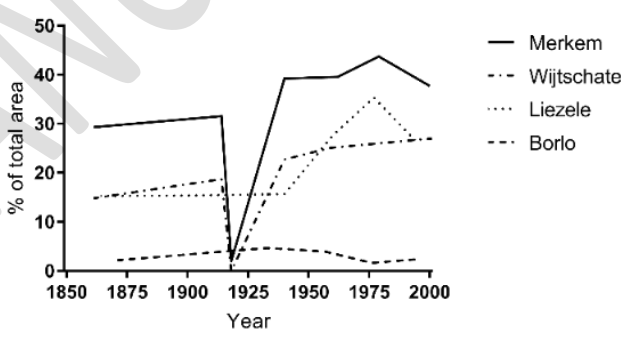

Tree rows

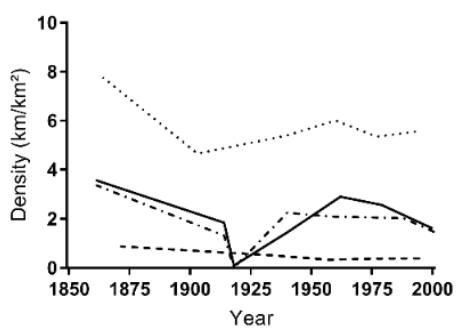

- Merkem

... Wijtschate

.... Liezele

-.. Borlo

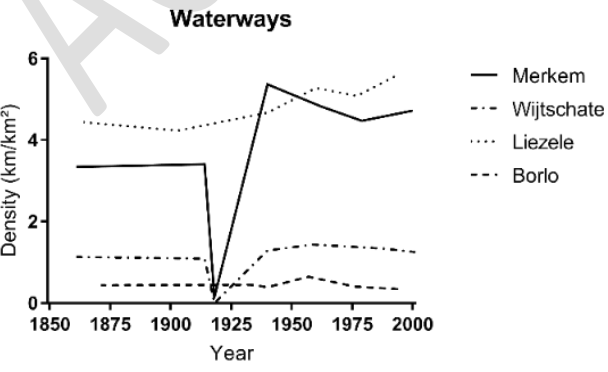

Figure 6: Time series evolution of various land use classes for the four study sites (c. 1860 c. 2000). 

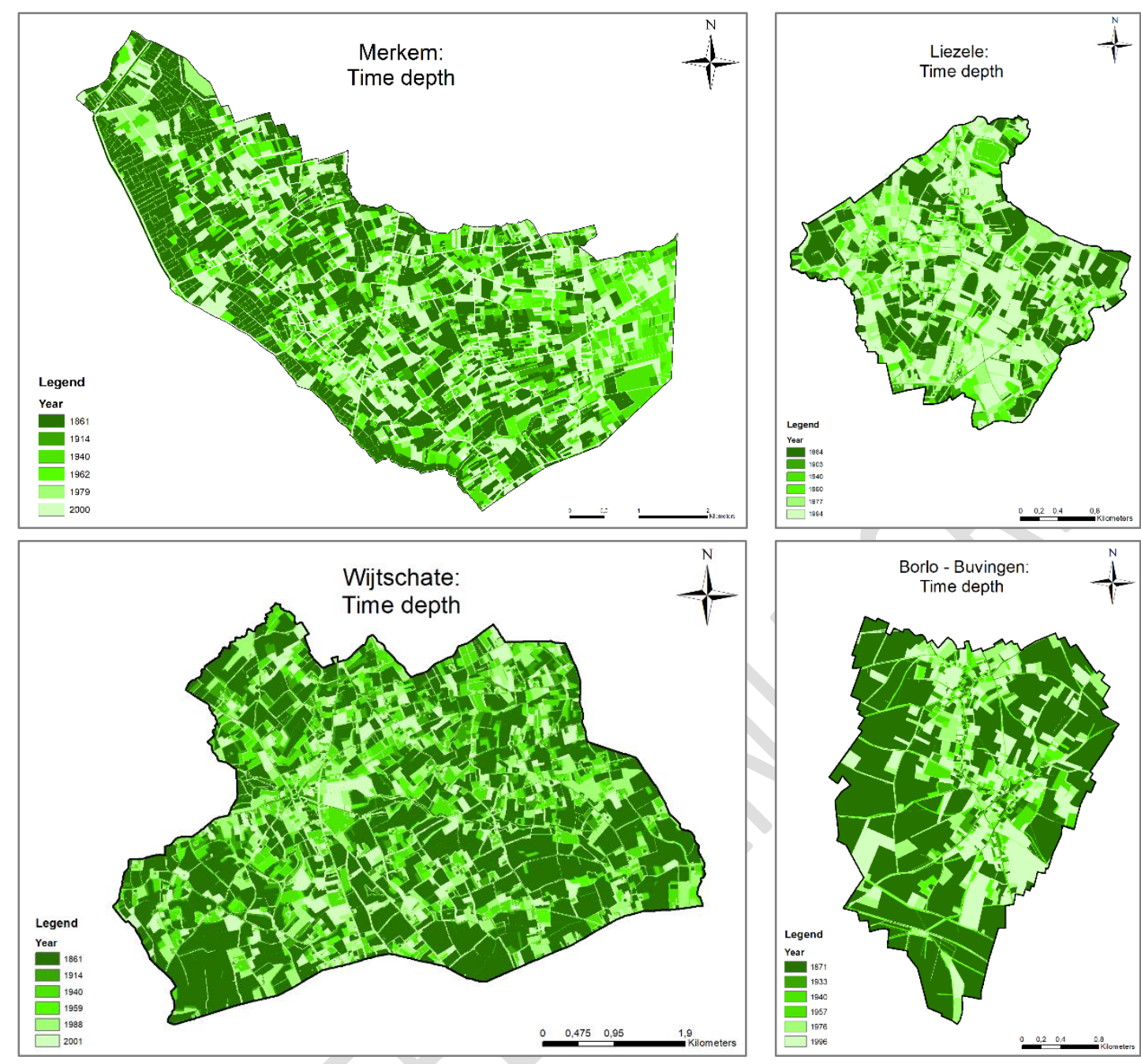

Time Depth Graph

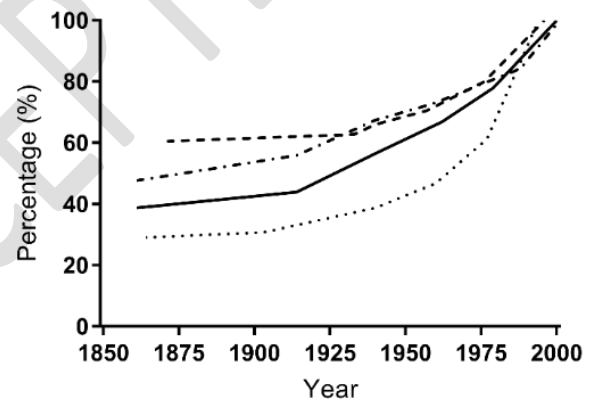

- Merkem

... Wijtschate

.... Liezele

-.. Borlo

Figure 7: Time depth analysis for the four study sites (c. 1860- c. 2000). The time depth maps show the period of the introduction of actual land use. The time depth graphs show which fraction of the actual land use dates back to a certain time period. 

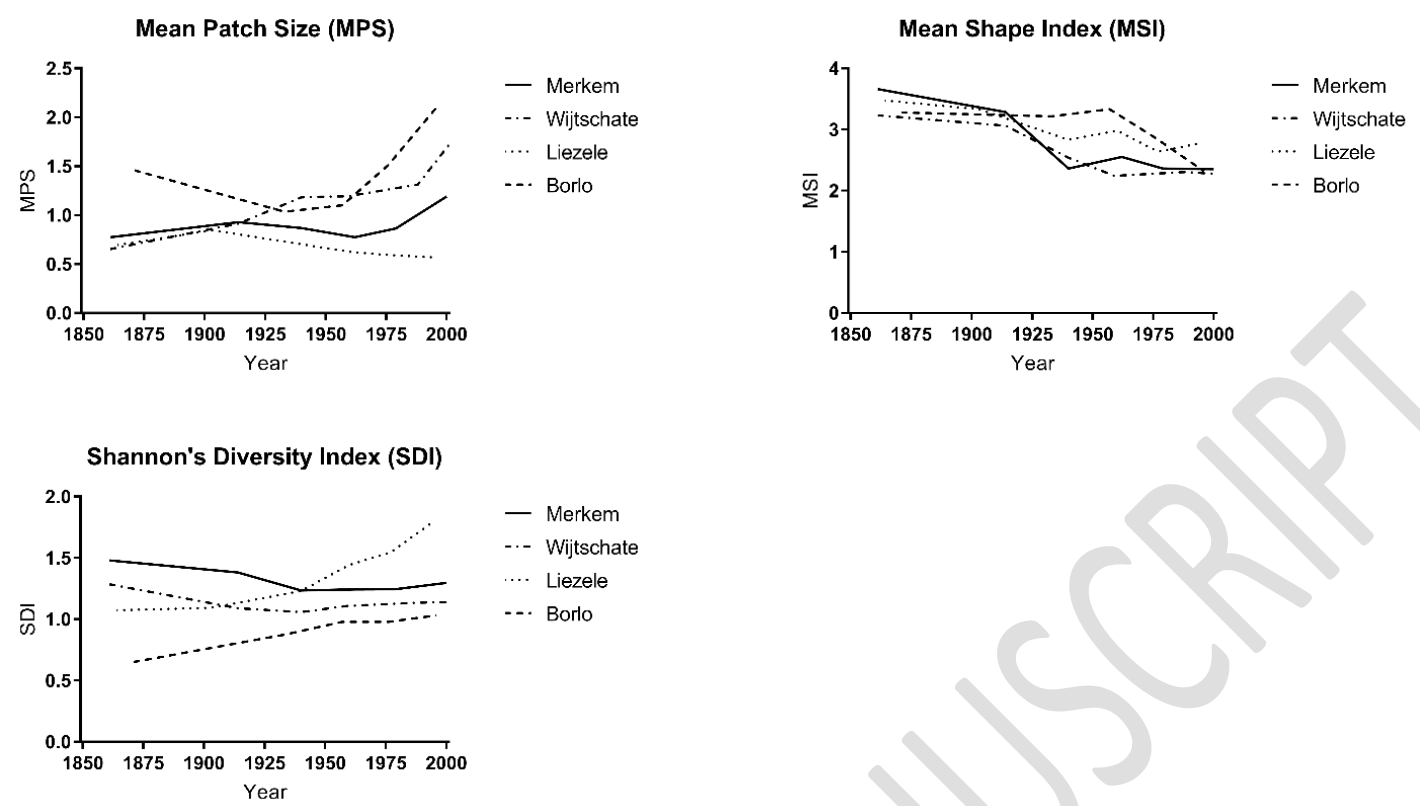

Figure 8: Landscape metrics (MPS, MSI and SDI) for the four study areas (c. 1860-2000). In Borlo-Buvingen the tree and hedgerows were not mapped due to the small scale of the aerial photographs of WWII. Therefore, this time period was not used in the calculation of landscape metrics. 



Figure 9: Changes in landscape visibility through time for the four study sites. Visibility is expressed as the mean percentage of the landscape that can be seen from 50 random selected points on the road network in each time period within a radius of $200 \mathrm{~m}$ from that point. 


\section{Tables}

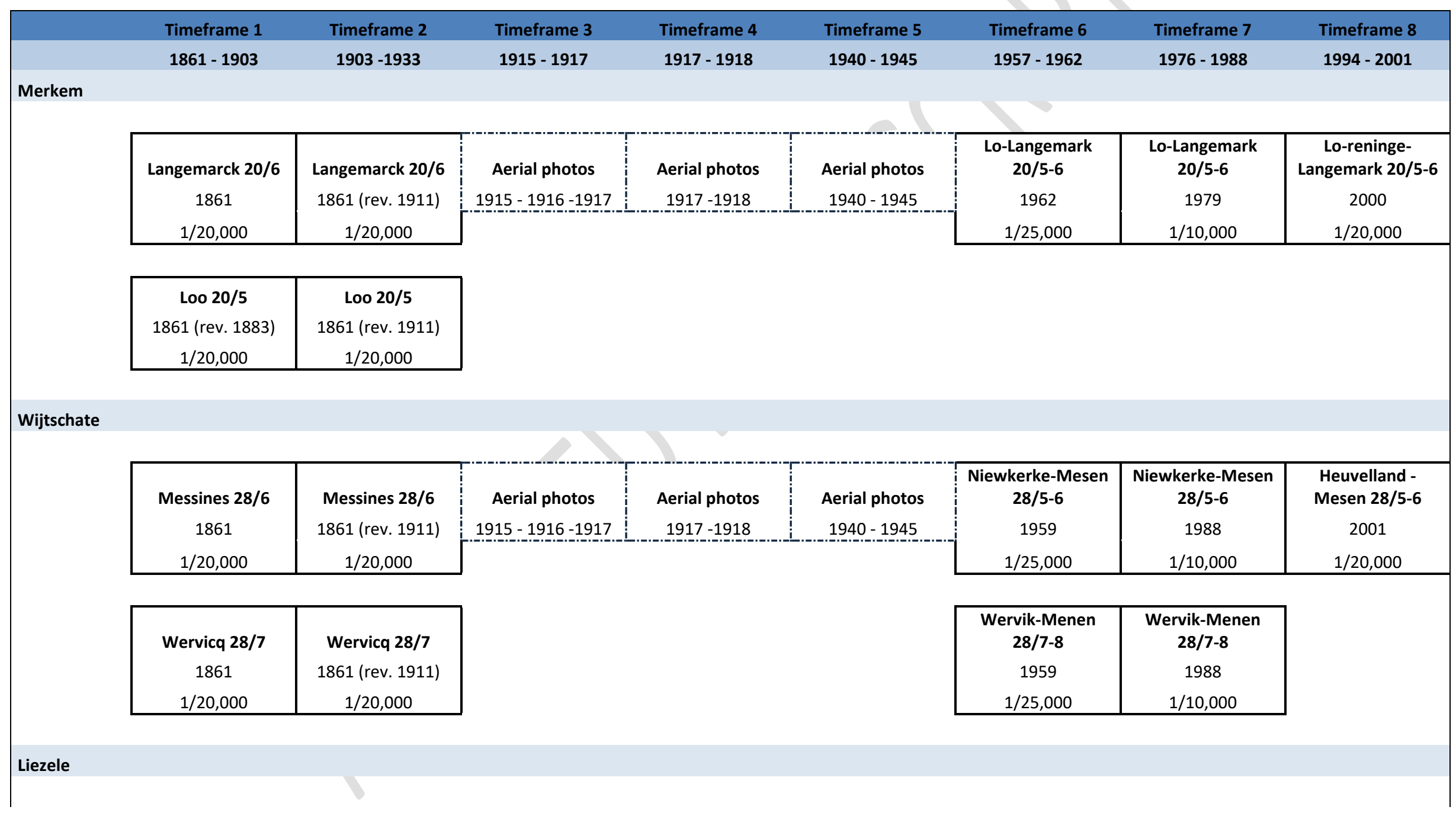




\begin{tabular}{|c|c|}
\hline Puers 23/2 & Puers 23/2 \\
1864 & 1864 (rev. 1903) \\
$1 / 20,000$ & $1 / 20,000$ \\
\hline
\end{tabular}

\begin{tabular}{|c|c|c|c|}
\hline Aerial photos & $\begin{array}{c}\text { Dendermonde- } \\
\text { Puurs 23/2 }\end{array}$ & $\begin{array}{c}\text { Dendermonde- } \\
\text { Puurs 23/2 }\end{array}$ & $\begin{array}{c}\text { Dendermonde - } \\
\text { Sint-Amands 23/1- } \\
\mathbf{2}\end{array}$ \\
\hline $1940-1945$ & 1960 & 1977 & 1994 \\
$1 / 25,000$ & $1 / 10,000$ & $1 / 20,000$ \\
\hline
\end{tabular}

Borlo-

Buvingen

\begin{tabular}{|c|c|}
\hline St Trond 33/6 & St Trond 33/6 \\
1871 & 1871 (rev. 1933) \\
$1 / 20,000$ & $1 / 20,000$ \\
\hline
\end{tabular}

\begin{tabular}{|c|c|c|c|}
\hline Aerial photos & Landen-Sint- & Landen-Sint- & Landen - Sint- \\
Truiden 33/5-6 & Truiden 33/5-6 & Truiden 33/5-6 \\
$1940-1945$ & 1957 & 1976 & 1996 \\
$1 / 25,000$ & $1 / 10,000$ & $1 / 20,000$ \\
\hline
\end{tabular}

\begin{tabular}{|c|c|}
\hline Montenaeken 41/2 & Montenaeken 41/2 \\
1876 (rev. 1903) & 1876 (rev. 1903) \\
$1 / 20,000$ & $1 / 20,000$ \\
\hline
\end{tabular}

\begin{tabular}{|c|c|c|}
\hline Hannut- & Hannut- & Hannut-Geer 41/1- \\
Montenaken 41/2 & Montenaken 41/2 & $\mathbf{2}$ \\
1958 & 1976 & 1995 \\
$1 / 25,000$ & $1 / 10,000$ & $1 / 20,000$ \\
\hline
\end{tabular}

Table 1: Overview of the topographic sources used in this study 


\begin{tabular}{|c|c|c|c|}
\hline Class & Legend & Description & $\begin{array}{l}\text { Buffer } \\
\text { (m) }\end{array}$ \\
\hline Arable land & Arable land & Surface dominated by crops to harvest & / \\
\hline Pasture & Pasture & Surface dominated by grasses & / \\
\hline Built-up area & Built-up area & Surface dominated by buildings and gardens & / \\
\hline Orchard & Orchard & Surface dominated by fruit or nut trees & / \\
\hline Forest & Forest & Surface dominated by trees & / \\
\hline Wetland & \multirow[t]{3}{*}{ Other } & Surface dominated by a wet soil & I \\
\hline Heath & & Surface dominated by heather vegetation & I \\
\hline $\begin{array}{l}\text { Recreation } \\
\text { area }\end{array}$ & & Surface dominated by sports fields & l \\
\hline Disturbed area & Disturbed area & $\begin{array}{l}\text { Surface without active land use and } \\
\text { dominated by bomb craters, treadmills, } \\
\text { intentionally flooded areas and ruins }\end{array}$ & / \\
\hline Tree row & Tree row & $\begin{array}{l}\text { a row of trees, often at field parcel } \\
\text { boundaries }\end{array}$ & l \\
\hline Hedgerow & Hedgerow & a hedgerow, often at field parcel boundaries & l \\
\hline Water & \multirow[t]{4}{*}{ Water } & Surface dominated by a pond or pool & / \\
\hline Canal & & $\begin{array}{l}\text { Surface dominated by an artificial } \\
\text { (navigable) waterway }\end{array}$ & $18 \mathrm{~m}$ \\
\hline Ditch & & $\begin{array}{l}\text { Surface dominated by an artificial waterway, } \\
\text { smaller than a canal }\end{array}$ & $1 \mathrm{~m}$ \\
\hline River & & $\begin{array}{l}\text { Surface dominated by natural or partial } \\
\text { natural water flow }\end{array}$ & $2 \mathrm{~m}$ \\
\hline Paved road & \multirow[t]{4}{*}{ Roads } & $\begin{array}{l}\text { Surface dominated by paved or partially } \\
\text { paved road }\end{array}$ & $6 \mathrm{~m}$ \\
\hline Unpaved road & & Surface dominated by an unpaved road & $2 \mathrm{~m}$ \\
\hline Path & & $\begin{array}{l}\text { Surface dominated by a unpaved road } \\
\text { smaller than class 'unpaved road' }\end{array}$ & $1 \mathrm{~m}$ \\
\hline Railway & & Surface retained for rail traffic & $5 \mathrm{~m}$ \\
\hline
\end{tabular}

Table 2: List of the selected land use types and their definitions 


\section{Appendices}

Appendix 1: Time series maps of Wijtschate
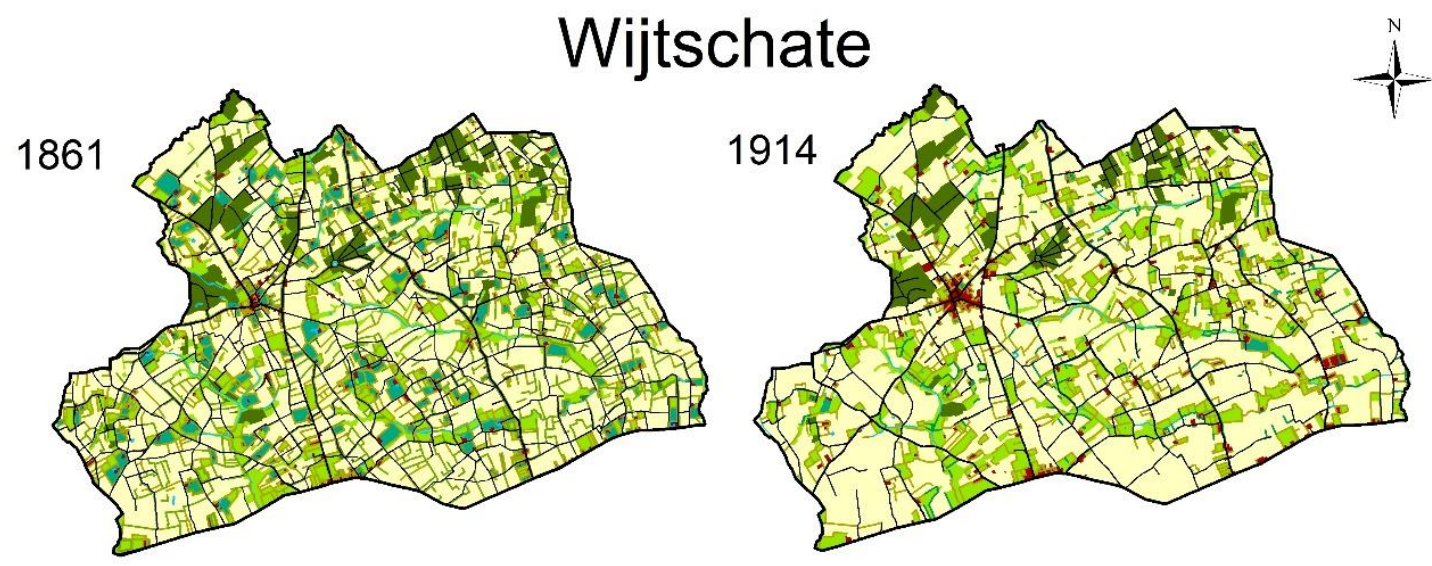

1918
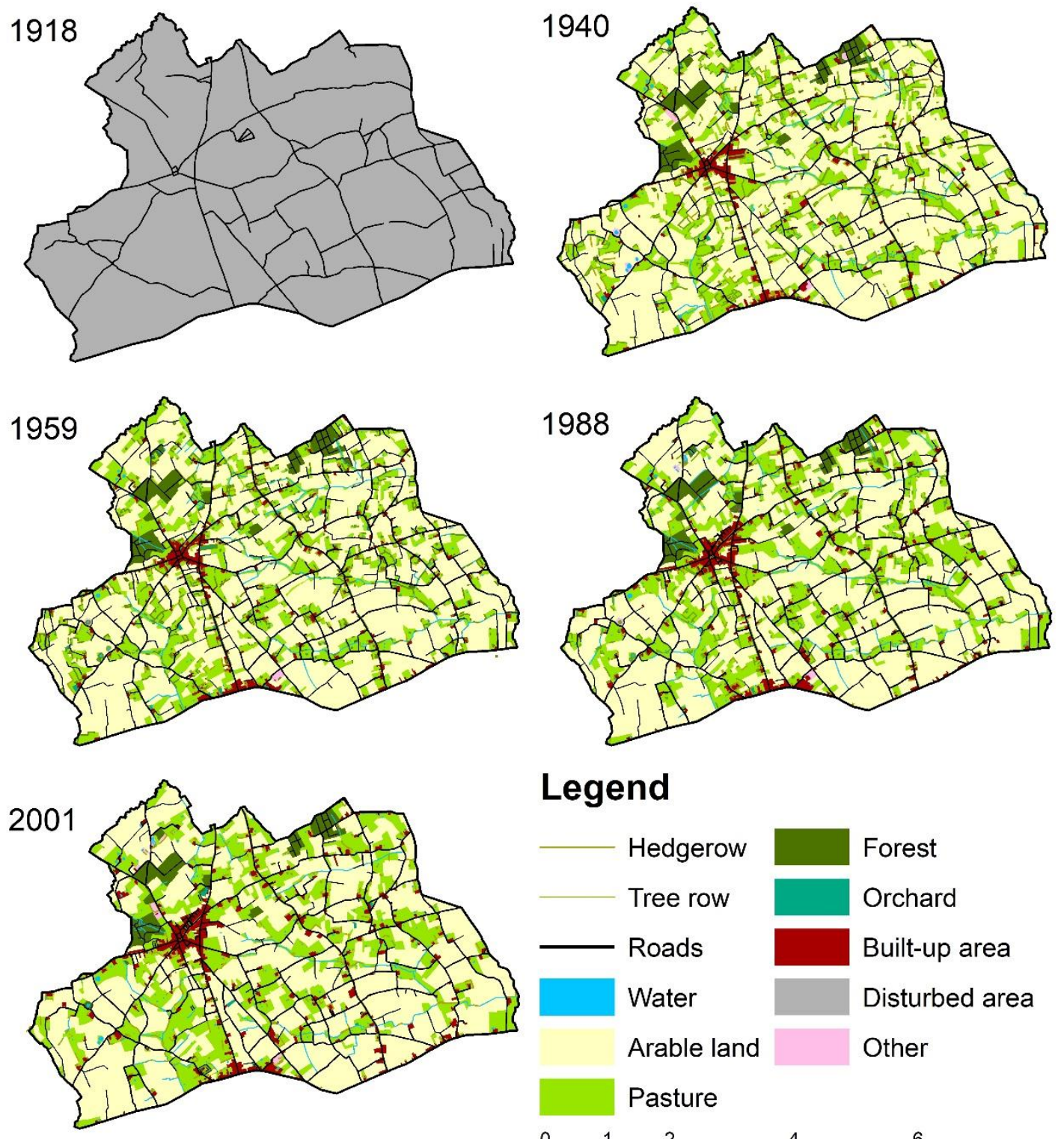

\section{Legend}

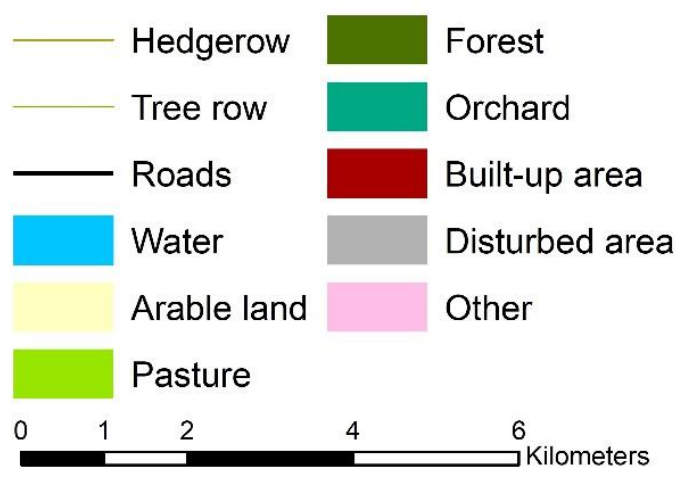


Appendix 2: Time series maps of Liezele

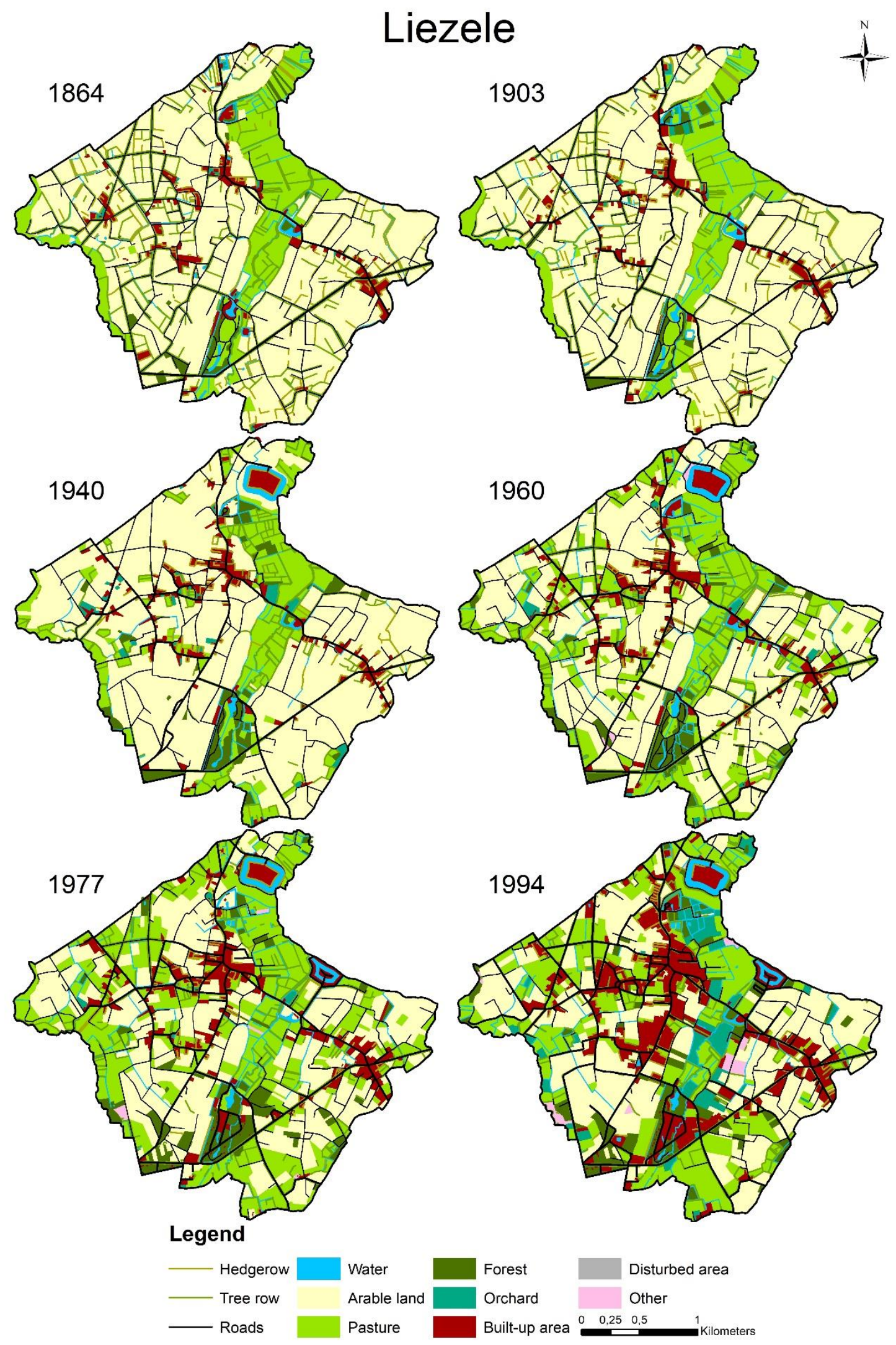


Appendix 3: Time series maps of Borlo-Buvingen



